\title{
THE FECAL FLORA OF TYPHOID FEVER AND ITS REACTION TO VARIOUS DIETS*
}

\author{
JOHN C. TORREY \\ (Department of Experimental Pathology, Loomis Laboratory, Cornell University Medical \\ College, New York)
}

Altho the typhoid bacillus itself has been the subject of many investigations and much is known in regard to its biology and its pathogenesis, little exact information has been acquired in reference to the intestinal bacterial conditions which may be associated with an invasion by this bacillus. To be sure, typhoid fever is no longer to be regarded as essentially an intestinal disease, yet bacterial conditions in the intestines may be conceived to be such, in certain cases, as to add the weight of the toxic products of putrefaction to the human organism already oppressed by the typhoidal virus; in other patients, the fecal flora may be of a type which permits the most favorable digestion and absorption of the food administered.

As is well known, Coleman, ${ }^{1}$ for a number of years, has been placing his typhoid patients on a high calory diet in order to reduce to a minimum the severe loss of nitrogen and weight which usually occurs in such cases when kept on a low calory diet. In connection with these cases in addition to careful clinical histories, a very accurate record is kept of the amounts of carbohydrate, fat, and protein consumed daily by each patient. The conditions are, accordingly, such as to present a most favorable opportunity to study the dietetic response of the typhoidal intestinal flora, and through the courtesy and cooperation of Dr. Warren Coleman the material for this study has been available.

As far as I am aware, this investigation is the first in which an attempt has been made to correlate conditions and changes in the fecal flora of human subjects with exact data in regard to the constitution of the diet utilized. It seems not unlikely that information of this character may give a clue to the most favorable dietaries for various infections, especially those involving the digestive tract. As Herter ${ }^{2}$ has well suggested in connection with a general discussion of intestinal

* Received for publication November 6, 1914.

1. Schaffer and Coleman: Arch. Int. Med., 1909, 4, p. 538.

2. Bacterial Infections of the Digestive Tract, New York, 1907, p. 181. 
infections, "Our attention has, perhaps, been too exclusively fixed on the specific excitants, and the rôle played by associated bacteria must receive more study for it is clear that they sometimes play a significant part in determining the outcome of an infection. The difference that decides whether a man will live or die must frequently be a slight one looked at from the standpoint of the processes of battle within the body."

It has been repeatedly observed that a diet containing large amounts of carbohydrate not only encourages the development of a fermentative flora, but also, as Kendalls has recently pointed out, tends to protect the protein in the food from putrefactive decomposition, not alone by the obligate putrefactive bacteria, but also by members of the colon and proteus groups capable of exercising either putrefactive or fermentative activities. Altho much laboratory evidence has been advanced in support of this principle, little definite information has been adduced in regard to the amount of carbohydrate which should be incorporated in the diet of adults in order to bring about this result or in regard to the uniformity and degree to which this is effected in individuals with various types of fecal flora.

In this study, the aim has been to determine the biological propensities and activities of the fecal flora as a whole, rather than to isolate and classify individual bacteria which may happen to be present in the stools and in regard to numbers and significance of which there is no definite criterion. In order to effect this purpose, the methods introduced by Herter ${ }^{4}$ and elaborated by Herter and Kendall, ${ }^{5}$ in their feeding experiments with monkeys, and by MacNeal, Latzer, and Kerr, ${ }^{6}$ in a study of the normal intestinal flora of man, have been adopted with some modifications. Altho the determination of the general type of flora has been the primary objective, the identification of bacterial types has always been effected when it would seem to serve a useful purpose.

This investigation was carried out during a part of the years 19121913.

During this period, a total of over one hundred stools from twenty-two typhoid patients have been examined. In a few instances, only a single specimen from a patient was subjected to the various procedures, but in twelve

3. Jour. Med. Research, 1911, 25, p. 117; Kendall and Farmer: Jour. Biol. Chem., $1912-13,13$, p. 63 .

4. Bacterial Infections of the Digestive Tract, New York, 1907, p, 181

5. Jour. Biol. Chern., 1909-10, 7, p. 203.

6. Jour. Infect. Dis., 1909, 6, pp. $123,571$. 
cases a series of four to seventeen stools were investigated. With a few exceptions, these patients were from the metabolism ward of the second medical division of Bellevue Hospital. After October 1, 1913, the Russell Sage Institute of Pathology was in charge of this ward. It is a pleasure to acknowledge the assistance of Dr. Eugene F. DuBois and others of the Russell Sage Institute. I also wish to thank Dr. N. M. Keith of the New York Hospital for his aid.

\section{MeTHods}

The material collected for examination was generally a part of a movement occurring between 6 and 7 o'clock in the morning. The stool was received in a sterile bed pan and a part transferred to a sterile bottle. These specimens were kept on ice during the few hours which might elapse before examination. As a number of the patients were inclined to constipation, it was frequently necessary to use an enema, consisting generally of a sterile normal saline solution.

With all the specimens, except those from fluid stools, a definite weighed amount of feces was used in seeding the various culture media. In making the dilutions of the feces, a method similar to that of $\mathrm{MacNea}^{\mathrm{b}}$ was followed, viz., $500 \mathrm{mg}$. of fecal matter, representative of the whole specimen as regards moisture and consistency, were carefully weighed in a large sterile watch glass. This material was then thoroughly emulsified in 50 c.c. of normal salt solution and poured into a small flask. Each cubic centimeter, accordingly, held the equivalent of $10 \mathrm{~m} g$. of the fecal matter. With fluid stools, an emulsion was made to the same density as one of these weighed preparations. From this primary emulsion, smears were made and treated with gram stain for microscopical examination and differential count.

A series of dilutions of the fecal emulsion at $1-10,1-100,1,-1,000$, and $1-10,000$ were next prepared and from suitable dilutions, using 1 c.c. in each case, poured plates were made with sugar-free agar, 1 percent lactose agar, and standard nutrient gelatin. These media were all titrated +1.0 to phenolphthalein. The sugar-free agar plate was incubated aerobically and the lactose agar plate anaerobically at $37 \mathrm{C}$. Definite amounts of the diluted material were also spread on large Endo plates with sterile glass rods. The Endo medium was prepared in accordance with Kendall and Day's ${ }^{7}$ modification. After twentyfour hours' incubation, typhoid-like colonies on the Endo plates were transferred to Russell's ${ }^{8}$ double sugar medium and characteristic growths were subjected to agglutination and cultural tests.

The following media were seeded with 0.5 c.c. of the primary fecal emulsion: Fermentation tubes containing sugar-free meat infusion peptone broth plus 1 percent dextrose, lactose, and saccharose; a fermentation tube containing litmus milk; and tubes containing $\mathrm{N} / 20, \mathrm{~N} / 10$, and $\mathrm{N} / 5$ acetic acid dextrose broth. This acetic acid medium was prepared in the following manner: Acetic acid was added to 1 percent dextrose meat infusion peptone broth until the reaction became N/5 acid to phenolphthalein. Part of this was then diluted with neutral dextrose broth until the $\mathrm{N} / 10$ and $\mathrm{N} / 20$ titrations were obtained. The three lots of this medium were tubed in 10 c.c. amounts and plugged with paraffined cotton. These tubes were incubated at $37 \mathrm{C}$.

The undiluted feces were used in seeding the following media: About 0.5 gm. was emulsified in the open arm of a large fermentation tube containing lactose peptone bile; a loop was streaked on a slant of Loeffler's serum medium;

7. Jour. Med. Research, 1911, 25, p. 95.

8. Ibid., p. 217 . 
and a stab culture was made in nutrient gelatin. The bile and serum media were incubated at $37 \mathrm{C}$. and the gelatin was incubated at room temperature.

About 10 c.c. of a 1-10 dilution of the original fecal emulsion were heated at $80 \mathrm{C}$. for fifteen minutes for spore cultures. One cubic centimeter was plated in sugar-free agar and in lactose agar, and also, in some instances, the same amount was added to fermentation tubes, containing milk with defibrinated rabbit or dog blood added, and to lactose blood-agar plates. These cultures were incubated at $37 \mathrm{C}$.

All the plate cultures containing lactose were incubated at $37 \mathrm{C}$. under anaerobic conditions. The method of Zinsser ${ }^{\circ}$ was followed in making these anaerobic plate cultures and proved entirely satisfactory. To insure a higher degree of anaerobiosis and to protect the surfaces of the seeded plates from the pyrogallic sodium hydrate solution, the hardened inoculated medium was covered with a layer of sterile agar.

After twenty-four hours' incubation, the Endo plates, the sugar-free agar plates, and the fermentation tubes were examined and the results recorded. After forty-eight to seventy-two hours, the examination included the gelatin and the anaerobic plates, and also the acetic acid cultures. The spore cultures were incubated several days.

The gram stain, used in coloring the smears from the fecal emulsion and the sediments of the fermentation tubes, was prepared and employed as recommended by Elser and Huntoon. ${ }^{10}$ The staining procedures were similar in each instance, except that the period of decolorization with absolute alcohol was varied in accordance with the thickness of the smear. In a number of instances, the results with this method were compared with results from the use of preparations decolorized with xylol and anilin oil followed by methyl alcohol, as recommended by MacNeal for work of this character. Sharper differentiation, however, was obtained by the treatment with absolute alcohol. A total of 300 bacteria was counted from each specimen and the results expressed in percentages. I am indebted to Mr. A. H. Rahe, my assistant, for many differential bacterial counts.

\section{SIGNIFICANCE OF THE VARIOUS TESTS}

The several procedures followed in these examinations were selected because, taken as a whole, they seemed to give a composite picture of the character of the stool and, through them, changes in the fecal flora following modifications in the diet could be satisfactorily followed. The general purpose of each test is as follows :

Endo Plates.-The primary object in the use of these plates was to gain an insight into the general character of the viable aerobic flora of the stool. With a little experience, it is possible from a mere inspection of these plates to identify a considerable number of different types of bacterial colonies, such as B. coli, B. lactis aerogenes, B. alkaligenes, the colon types which do not act on lactose and which for convenience are designated B. paracoli in the tables, also B. pyocyaneus, B. proteus, streptococcus, and staphylococcus. In the tables, the relative number of colonies appearing on these plates is indicated by the number of

9. Jour. Exper. Med., 1906, 8, p. 542.

10. Jour. Med. Research, 1909, 20, p. 377. 
crosses, and the most numerous types of bacterial colonies are written below in order of prevalence. A search was always made for typhoid colonies and, as two or more plates with a favorable distribution of colonies were almost always obtained, viz., $250-300$ colonies on a plate, the failure to find any typhoid colonies indicated that these bacilli were present in the feces in small numbers, if at all. Ficker and Hoffmann ${ }^{11}$ estimated that, with the Drigalski plate medium, the isolation of typhoid bacilli from stools was unlikely in cases where the viable fecal bacteria outnumbered the typhoid bacilli more than 300 to 1 . In this series of patients on the high calory diet, the typhoid bacillus was isolated from the stools infrequently either from directly seeded Endo plates or from bile enrichment tubes.

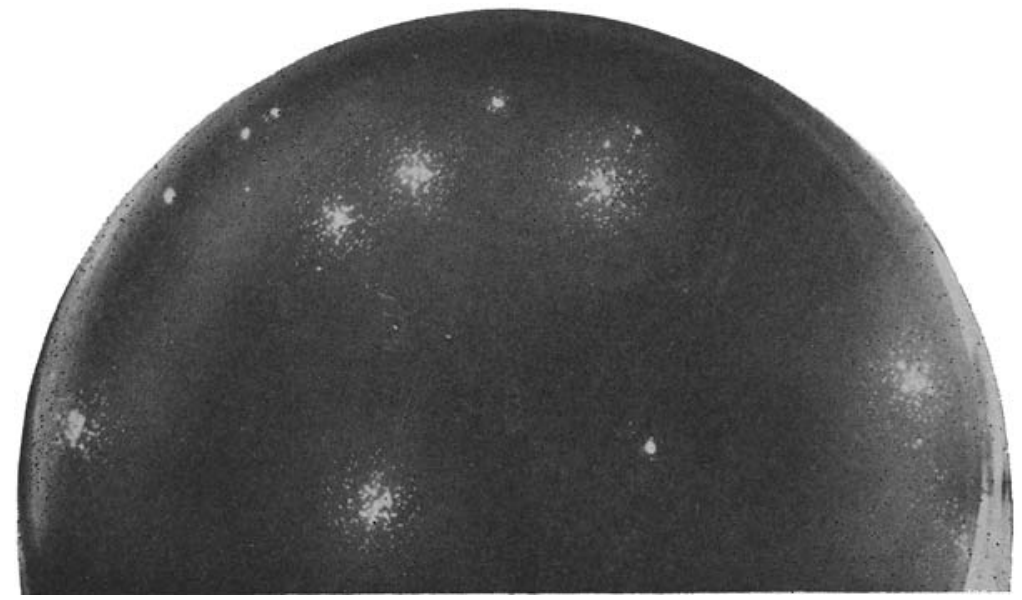

Fig. 1.-Lactose agar anacrobic plating, showing the grouping of the aciduric bacteria colony about a central colon colony. $X 1$.

Sugar-Free Agar Aerobic Plates and Lactose Agar Anacrobic Plates.-A comparison of these two culture plates has been found to give a very satisfactory index of the relative numbers of $B$. acidophilus which may be present in the stool. The various types of the colon group and the streptococci develop on both media, but the bacillus acidophilus and, at times, the bacillus bifidus appear only on the anaerobic lactose plates. The bacillus acidophilus develops very feebly, if at all, on media without sugar, and altho it will grow aerobically a higher degree of development occurs under anaerobic conditions. Such anaerobic lactose plates, seeded from stools containing many bacilli of

11. Arch. f. Hyg., 1904, 49, p. 229. 
the acidophilus type, exhibit a peculiar and characteristic grouping of the colonies. At suitable dilutions, the colonies are seen to be grouped in clusters. In the center, there is at least one large lenticular colony which may or may not have an associated bubble of gas. Clustered about these central colon bacillus colonies are smaller colonies, often in great numbers, which decrease in size with increasing distance from the central colony until, at the periphery, they become exceedingly minute. In the neighborhood of these colony groups, the medium is clouded. The smaller colonies are composed of the bacillus acidophilus or, at times, of the bacillus bifidus and it is evident that their development is initiated and favored by the acid and possibly other growth

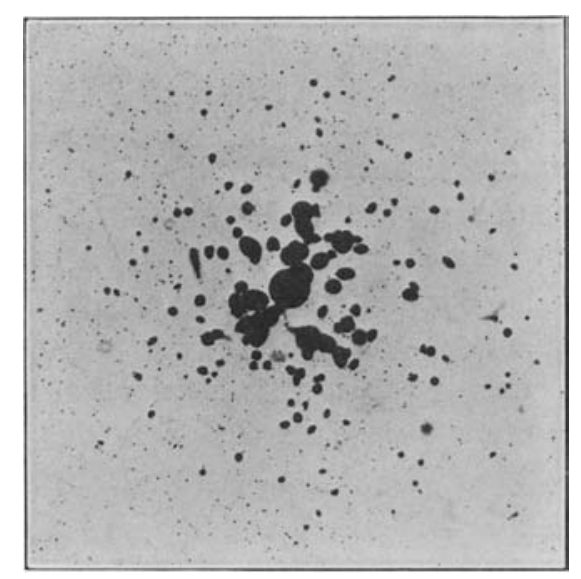

Fig. 2,-Detail of one of the clusters. X4.

products formed by the colon bacilli diffusing through the medium. These bacilli are evidently acidophilic as well as aciduric. ${ }^{12}$ In some instances, the large central colonies were found to be composed of aciduric bacilli. In the culture plates containing several hundred colon bacilli the development of these acidophilic bacteria may be uniform throughout the plate. The difference in the count on the anaerobic lactose agar plates, exhibiting this peculiar grouping of the colonies and clouding of the medium, and that on the sugar-free agar plates or gelatin plates may be considered a fair index of the number of viable acidophilic bacilli in the stool. In the tables directly under the count Med. Research, 1910, 22, p. 153. 
for the anaerobic lactose agar plates, the type of the predominating microorganism is stated.

Acetic Acid Glucose Broth.-Additional information in regard to the acidophilic flora is gained from an inspection of the tubes containing three strengths of acetic acid, each of which has been seeded with $5 \mathrm{mg}$. of the feces. Aside from yeasts, the bacillus acidophilus was the only organism found in these stools capable of multiplying in this acid medium. While the lactose agar anaerobic plates reveal the number of B. acidophiltus in the stool, the acid fluid media indicate especially the aciduric properties of these bacilli. Organisms which are capable of multiplying in a medium with an acidity of $\mathrm{N} / 10$, or even $\mathrm{N} / 5$, acetic acid have acquired marked acid resisting properties. An examination of stools from normal individuals, and also from those with a somewhat disturbed digestion, has shown that such highly aciduric bacilli are only rarely present in the intestinal tract. As a result, however, of a continued diet containing large amounts of carbohydrate associated with reduced amounts of protein and fat, such bacilli may be developed (Table 1). 'Their presence in the stool justifies the assumption that unusual amounts of lactic acid are being produced in the intestinal tract, especially in the region of the large intestine, which is the locality where these bacilli undergo their greatest development. It may also be assumed that carbohydrate is available in this locality for their metabolism.

Formentation Tubes.-Herter and his associates have laid much stress on the value of fermentation tubes containing sugar broths as an aid to the bacterial analysis of the feces. Because of the transition from almost complete anaerobiosis to aerobiosis which such tubes offer, they believed that the bacterial development in the tubes represents closely the viable organisms originally present in the feces. Furthermore, certain bacteria, such as the bacillus bifidus and the bacillus aerogenes capsulatus, altho present in such small numbers in the stool as to be overlooked, may be brought to strong development in these tubes. They asserted also that the volume of gas produced in tubes seeded with the feces is of significance, being much reduced from the normal 25-30 percent in certain intestinal disorders. Too much stress, however, should not be laid upon the volume of gas, as MacNeal, Latzer, and Kerr encountered a great variation in the amount produced in the case of twelve supposedly normal individuals exam- 
ined at frequent intervals for an extended period. Kendall ${ }^{13}$ has found that, under normal conditions of the digestive system, closely similar amounts of gas are formed in the dextrose, lactose, and saccharose tubes.

In the tables, the amounts of gas formed in twenty-four hours are expressed in percentages. As the length of the closed arm of the fermentation tubes varied considerably, the figures given have greater comparative value than those obtained by direct measurement in millimeters.

In these typhoid cases, there was no definite deviation from the normal average in the amount of gas produced. The stools of patients on the high calory diet in the earlier stages of the infection, and also patients on a milk diet (Table 5), showed, for the most part, a somewhat greater production of gas with dextrose than with the other two sugars, whereas in the later periods generally after a rather prolonged feeding with lactose, the maximum amount of gas was formed in lactose. As has been observed by others, stools containing an abnormal proportion of streptococci give rise to a much reduced amount of gas, especially in the saccharose tube. In the cases of John T. (Table 1) and Howard F. (Table 3), this was regularly the case as regards saccharose. On the other hand, with increasing numbers of the bacillus acidophilus in the stools, the productions of gas in the dextrose and lactose tubes remained about equal. The largest amounts of gas did not occur during periods when the patients were fed large amounts of carbohydrates, as might be expected, but were encountered when the amount of fat in the diet was increased, and especially when the proportions of fat and protein to the carbohydrate were raised (Table 1, Enrico P.; Table 2, Christian M.; Table 5, Joseph P. and Torello D.).

A much larger amount of gas was regularly formed in the lactose bile fermentation tube than in the lactose broth tube, which was due, in part, to the heavier seeding of the former. These bile tubes offered an enrichment medium for the typhoid bacillus, which was of doubtful value; they were chiefly of service in permitting the development of the bacillus aerogenes capsulatus and other spore-bearing anaerobes of a more or less putrefactive type. An examination of the sediments from these tubes threw some light on the question of the fermentative or putrefactive nature of the feces with which they were seeded. Accordingly, these sediments have been classified in the tables in

13. Jour. Biol. Chem., 1909-10, 6, p. $25 \%$. 
reference to their probable potential activity. Thus, smears from sediments showing a majority of the organisms of the bacillus acidophilus type are designated fermentative; those in which the larger numbers of the bacteria are of the colon and streptococcic types are termed peptolytic; while smears in which there were many bacilli of the aerogenes capsulatus type, together with other spore-bearing bacilli are classified as putrefactive.

Another medium regularly employed in fermentation tubes was litmus milk. Stools, in which the bacillus acidophilus is predominant, generally form a rather soft clot with little or no gas; with many streptococci, the clot is firmer and there is little gas; with the ordinary stool of the adult the clot is solid and shrunken, whey is expressed from the clot and there is formed 20-50 percent of gas. A production of 100 percent gas generally, but not always, means the presence of large numbers of $\mathrm{B}$. welchii. The principal object in using these milk fermentation tubes was to detect the presence of bacteria able to digest casein under anaerobic conditions. For this purpose, the tubes were kept under observation for a period of about ten days. This occurred only rarely and in a moderate degree.

Loeffler Serum Medium Slant and Gelatin Stab Culture.-These media were inoculated with the undiluted feces in order to gain an idea of the relative numbers of bacteria in the various stools capable of digesting proteins of this character. The aerobic liquefying bacteria are supposed to develop especially in the small intestine. Herter and Kenda1 $1^{5}$ determined, through feeding experiments, that the fecal flora of monkeys, placed on a high protein diet, caused a rapid liquefaction of these media, whereas when the monkeys were given a diet consisting largely of carbohydrate slight or no digestion occurred. With typhoid patients exhibiting a fermentative flora, there occurred slight or no digestion of serum medium, whereas the liquefaction of the gelatin medium was often marked.

Spore-Bearing Bacteria.--As has already been mentioned a suspension of the feces to the amount of $1 \mathrm{mg}$. per cubic centimeter was heated at $80 \mathrm{C}$. for fifteen minutes. One cubic centimeter of this heated suspension was plated in sugar-free agar and incubated aerobically at 37 C.; 1 c.c. in lactose agar and incubated aerobically at $37 \mathrm{C}$.; and in some instances, 1 c.c. was plated anaerobically in lactose agar to which 1 c.c. of defibrinated blood had been added and also 
seeded in blood milk fermentation tubes, both being incubated at $37 \mathrm{C}$. The last two media favored especially the development of $\mathrm{B}$. welchii. Comparative results indicated that about ten times as many spores of this type would develop in the blood lactose agar plates as in the same media without blood. When these spores were present in small numbers in the stools, under 40 per milligram, the characteristic growth reaction with disruption and partial digestion of the curd might be delayed for forty-eight to seventy-two hours.

MacNeal found in normal human stools an average per milligram of 65 spores developing aerobically and 1,790 anaerobically. In these stools from typhoid cases on the high calory diet, I have rarely found as many spores as this; in fact, in many instances, no colonies at all developed on the plates seeded with the heated suspension of the feces. Those which did appear on the anaerobic plates were almost invariably of the bacillus welchii type. Their occurrence in relation to the diet will be discussed in the following section.

Direct Smears from the Feces Stained with Gram's Method.-In the original tabulations of the bacteria observed in the gram-stained fecal smears, fourteen different types were enumerated. In compiling the tables, however, it has been ncessary to condense this enumeration and to group the bacteria under a few general types, which may lay claim to some distinction in morphology or staining, and which reacted definitely to changes in diet. The gram-negative bacilli were almost entirely of the colon type. The gram-negative cocci were present in such small numbers, if at all, as to be negligible. No spirochetes were observed. Within the aciduric bacilli group have been placed nearly all of the gram-positive rods without spores seen in the fecal smears. A study of pure cultures of aciduric bacilli isolated from these stools has shown that they may vary markedly in morphology. The most frequently encountered type, taken for the bacillus acidophilus, was a rather long, slender bacillus, about 3-6 microns, with rounded ends and strongly gram-positive. This bacillus, however, often occurs as a gram-positive, rather short, plump rod, 1-3 microns, and with rounded ends. There are also gram-positive, long, thick rods which belong in the aciduric group, but which cannot, from their morphology alone, be distinguished from the non-sporebearing representatives of the bacillus aerogenes capsulatus. Certain gram-positive bacilli of the length of the first type of the bacillus acidophilus mentioned, but rather thicker, often curved and irregularly 
staining, and with a punctate or bifid end, were not infrequently encountered. These were regarded as representatives of the bacillus tifidus and placed in the aciduric group. Logan ${ }^{14}$ has recently directed attention to the marked polymorphism displayed by the various members of this acid-tolerant group.

The tables show a fairly close correspondence between the results obtained by the cultural procedures and the direct counts from the fecal smears. Of the two, however, the cultural tests give the more reliable information in regard to the actual bacterial conditions in the intestinal tract. This is due, in part, to the uncertainty of identification of the more important intestinal bacteria by morphology alone, and, in part, to the fact that an inspection of a gram-stained smear gives no information in regard to the viability of the bacteria. The number of viable bacteria in a stool in ratio to the total count has been estimated at anywhere from 1-100 (Klein) to 1-3,000 (MacNeal). Where there is a radical lack of correspondence in the tables between the cultural results and the direct count, it is probable that the discrepancy is due to an unusually large proportion of dead bacteria. This was especially apt to occur following marked changes in the diet.

In a number of cases, gram-stained smears from the sediments of the broth fermentation tubes after twenty-four hours' incubation were compared with direct counts from the stool. A comparison of sediments of the dextrose, lactose, and saccharose tubes, seeded from the same material, did not show any uniform difference in the character of the sediments, altho, in some instances, streptococci had multiplied more actively in the saccharose tube, and the bacillus bifidus appeared in larger numbers in the sediments from the dextrose and lactose tubes. The counts indicate, as Herter and Kendall ${ }^{15}$ have claimed, that the growths in these fermentation tubes represent, in a measure, the bacteria originally present in the feces. They are not present however in the same relative numbers. Streptococci and also the bacillus acidophilus, if present in any considerable numbers in the stool, always multiplied to such a degree as to far outnumber the colon bacillus types in the sediments. The most interesting type sometimes brought to active development was the bacillus bifidus. This occurred at times in tubes seeded with feces in the smears of which the bacillus bifidus was seen in very small numbers, or not at all.

14. Jour. Path. and Bacteriol., 1914, 18, p. 527.

15. Jour. Biol. Chem., 1908-9, 5, p. 283. 
It may be mentioned that in two watery stools with much mucus from two typhoid patients with active diarrhea the bacillus bifidus, including many bifid forms, was observed in the fecal smears in very large numbers, in one instance constituting 55 percent of the total bacteria, and in the other 29 percent. As this bifid bacillus has been encountered rarely in the stools of normal adults, its presence in such large numbers in these pathological adult stools is worthy of note.

\section{DESCRIPTION OF THE TABLES}

It was not feasible to attempt the detailed publication in a tabulated form of the findings in the total 103 stools examined. Accordingly, only a number of selected cases have been presented in such detail as space permitted. These, however, illustrate the salient features revealed in this work. In each of Tables 1-4 have been grouped two or more cases which illustrate the response of a certain type of fecal flora to various modifications of the high calory diet, while in Table 5 are given the results with a milk diet in two cases. In the following section, there is a discussion of the various types of flora encountered and their reactions to the different diets.

All of the counts from the plate cultures refer to the numbers of colonies appearing per milligram of the feces. The figures for the fermentation tubes indicate the percentage of gas formed. In indicating the degree of liquefaction of gelatin and Loeffler serum, the following symbols are used: \pm , slight; + , moderate; ++ , marked; +++ , rapid; ++++ , very rapid. As regards the amount of growth in the acetic acid glucose broth tubes: 1 means slight growth; + , moderate; ++ , heavy +++ , very heavy.

In Tables $1-4$, the average daily amounts of proteins, fats, and carbohydrates given each patient are expressed in grams. Unless otherwise stated, the figures signify the average for the period since the last examination. In the first column, the diet for each patient since admission to the hospital is described.

The following brief case-reports include only such of the patients on the high calory diet as are incorporated in the tables.

John T.-Twenty-five years old, admitted November 19,1912, on the eighth day of the disease. Onset five days ago with headache and vomiting. Since then the patient has had anorexia, malaise, and several nose bleeds. Looks fairly well nourished but weak and acutely ill.

On November 21, agglutination test positive and typhoid bacilli recovered from the blood; November 20, several rose spots' appeared, small abdominal 
hemorrhage in the evening; November 23, spleen palpable; November 25 , abdomen slightly tympanitic, phlebitis in right thigh; November 26 to 29 and on December 1 patient had chills; December 4, general condition improved, patient less stuporous; December 31, temperature shot to 103, both femoral regions painful and swollen; January 1, temperature normal. Right leg remained swollen during convalescence. Patient gained rapidly in weight.

Enrico P.-Twenty-four years old, admitted December 4, 1912, on the fourth day of the disease. Two days ago had severe cough with blood-tinged expectoration. Appetite failed and patient suffered from headache. Looked fairly well nourished, but acutely ill; many large and small moist râles in lungs; spleen palpable.

December 5, agglutination test positive and typhoid bacilli recovered from the blood, patient apathetic, expectoration and headache contintes, no rose spots; December 10, abdomen slightly distended, signs of bronchitis; December 14, spleen palpable $2 \mathrm{~cm}$. below costal margin, general condition good, nutrition good; January 3, stools continue green and contain mucus, diet almost exclusiely carbohydrate had not changed character of the stools, patient put on fat diet for three days, stools changed markedly, became light brown and formed, takes fat diet well; Jantiary 15, patient seems to have intolerance for lactose, whenever given 50 to $60 \mathrm{gm}$. shows distention, passes large amounts of gas and suffers considerable abdominal pain. Convalescence rapid. Patient kept for examination of feces.

Anthony G.-Eight years old, admitted August 19, 1913, on the eleventh day of the disease. About two weeks ago began to be apathetic, lost appetite, and suffered from headaches; in bed since August 15. Looked fairly well nourished and well developed; spleen not palpable; several rose spots; agglutination doubtful.

On August 23, severe abdominal pains, no sign of perforation, abdomen much distended; August 25, many rose spots, spleen palpable. No more abdominal distention. Convalescence rapid.

Christian M.-Thirty-one years old, admitted September 8, 1913, on the eleventh day of the disease. About two weeks ago began to have headaches and malaise, four days ago stopped work, next day developed diarrhea. Very well developed; apathetic.

On September 8, agglutination was positive and typhoid bacilli recovered from the blood, spleen not palpable, rose spots appeared in crops; September 19, pain and tenderness in right lumbar region lasting several days; October 4 to 15 , typhoid bacilli in urine and feces, disappearing later.

Thomas B.-. Sixty years old, admitted October 2, 1913, on the fifteenth day of the disease. For two weeks has suffered from malaise and anorexia; has been feverish. A large, well-developed man, looks acutely ill, apathetic.

On October 21, many rose spots, agglutination positive, blood culture positive for typhoid bacilli.

October 13, rose spots on abdomen and back, spleen not palpable; October 27 , uninterrupted convalescence; November 10 to 26 , serofibrinous pleurisy, fluid base of left lung.

Morris S.-Twenty-one years old, admitted August 17, 1913, on the seventh day of the disease. Seven days ago began to have pains in abdomen and back and since then loss of appetite and constipation. He has a short, small frame, well nourished; distinct pyorrhea alveolaris; spleen palpable.

On October 18, agglutination negative, blood culture positive for typhoid bacilli; October 22, complains of sore throat; October 23 , condition good, slightly apathetic, spleen palpable $4 \mathrm{~cm}$. below costal margin, abdomen slightly distended; 
October 24, agglutination positive; October 27, abdomen which was distended on high carbohydrate and very low fat diet became soft when the amount of fat was increased; October 30, a little irrational, color grayish, pulse soft; November 4, general condition improved; November 17, temperature rising, patient feels well, does not look sick; November 18, sharp pains right side of abdomen lasting a few hours; November 24, patient not toxic in this relapse; December 3, feels well, patient had frothy stools on high carbohydrate, but when amount of fat increased became normal; December 17 to 25 , second relapse, patient not at all sick, spleen not palpable, no rose spots. Throughout the long febrile period the patient's state of nourishment remained very good and convalescence was rapid.

Howard F.-Twelve years old, admitted November 4, 1913, on the fourth day of the disease. On October 26 severe headaches and malaise; October 29, developed chills and took to bed. His uncle, Charles F., living in the same house developed typhoid at the same time. Tall, well-developed boy; teeth good; good state of nutrition; spleen not palpable; several rose spots.

On November 8, condition good, rational but apathetic; November 12, signs of bronchitis; November 14, blood culture positive for typhoid bacilli ; November 17, takes food poorly, much emaciated, somewhat toxic; December 10, passed two ascarides. Convalescence rather slow, heart somewhat enlarged, action rapid on exertion.

Charles F.-Twenty-four years old, admitted November 4, 1913, on the eighth day of the disease. About a week ago lost appetite and since then has suffered from headaches and malaise. Medium frame, well nourished, spleen palpable, several rose spots.

On November 5, agglutination positive; November 6 , blood culture positive for typhoid bacilli; November 8 , rational, slightly toxic, several small intestinal hemorrhages; November 19, intestinal hemorrhage of about 250 c.c., patient much prostrated, takes food badly, many rose spots in crops; November 14 to 17, developed severe follicular tonsillitis, became very toxic and apathetic, pulse of poor quality; December 3, condition much improved. Convalescence fairly rapid.

Thomas F. Thirty-four years old, admitted August 22, 1913, on the fourteenth day; of the disease. About two weeks ago began to suffer from headaches and malaise. Well developed and well nourished; rough systolic murmur at base of heart; spleen not palpable.

On August 27, many rose spots; Angust 29, very apathetic; September 2, blood culture positive for typhoid bacillus, small abscesses on buttocks, has had much abdominal distention at times, irrational; September 5, abscesses incised; September 8, emaciation has been very rapid; September 12, showed much improvement. Convalescence rather slow.

Emil C.-Twenty-three years old, admitted August 23, 1913, on the fifth day of the disease. Five days ago suffered from fever, chills and headache; four days ago colicky pains in stomach, appetite good. Well nourished, does not look acutely ill; spleen palpable; doubtful rose spots.

On August 26, agglutination positive; August 29, blood culture positive for typhoid bacilli; September 1, more rose spots, severe headache; September 5, abdominal distention moderate; September 19 to 21 , complains of headache; September 24, began to relapse; September 26, temperature rose to $104 \mathrm{~F}$., spleen palpable $6 \mathrm{~cm}$. below costal margin, several rose spots. During convalescence, October 18 to 30 , temperature elevated, cause unknown. 


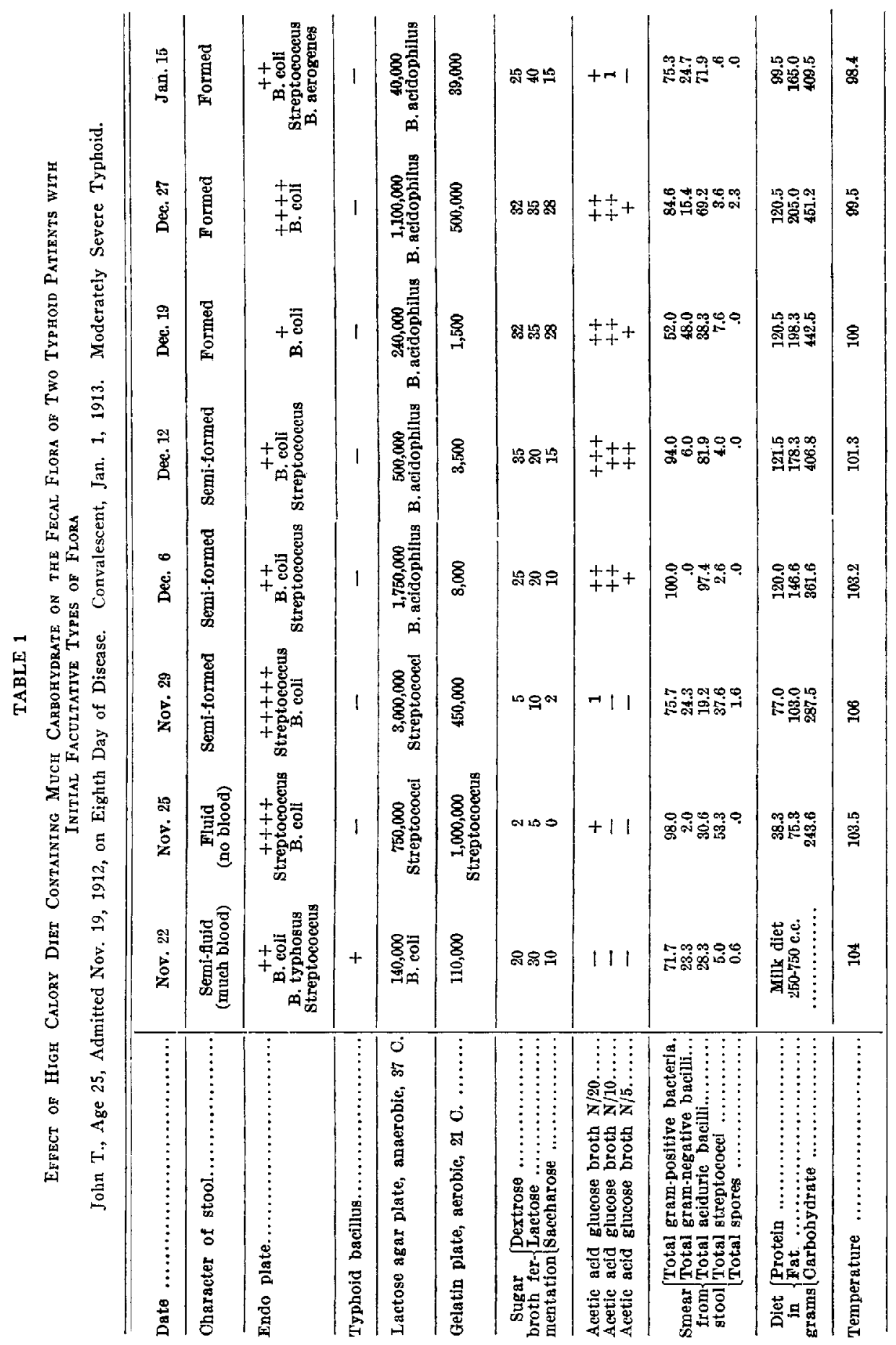

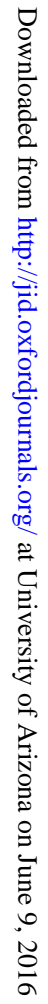




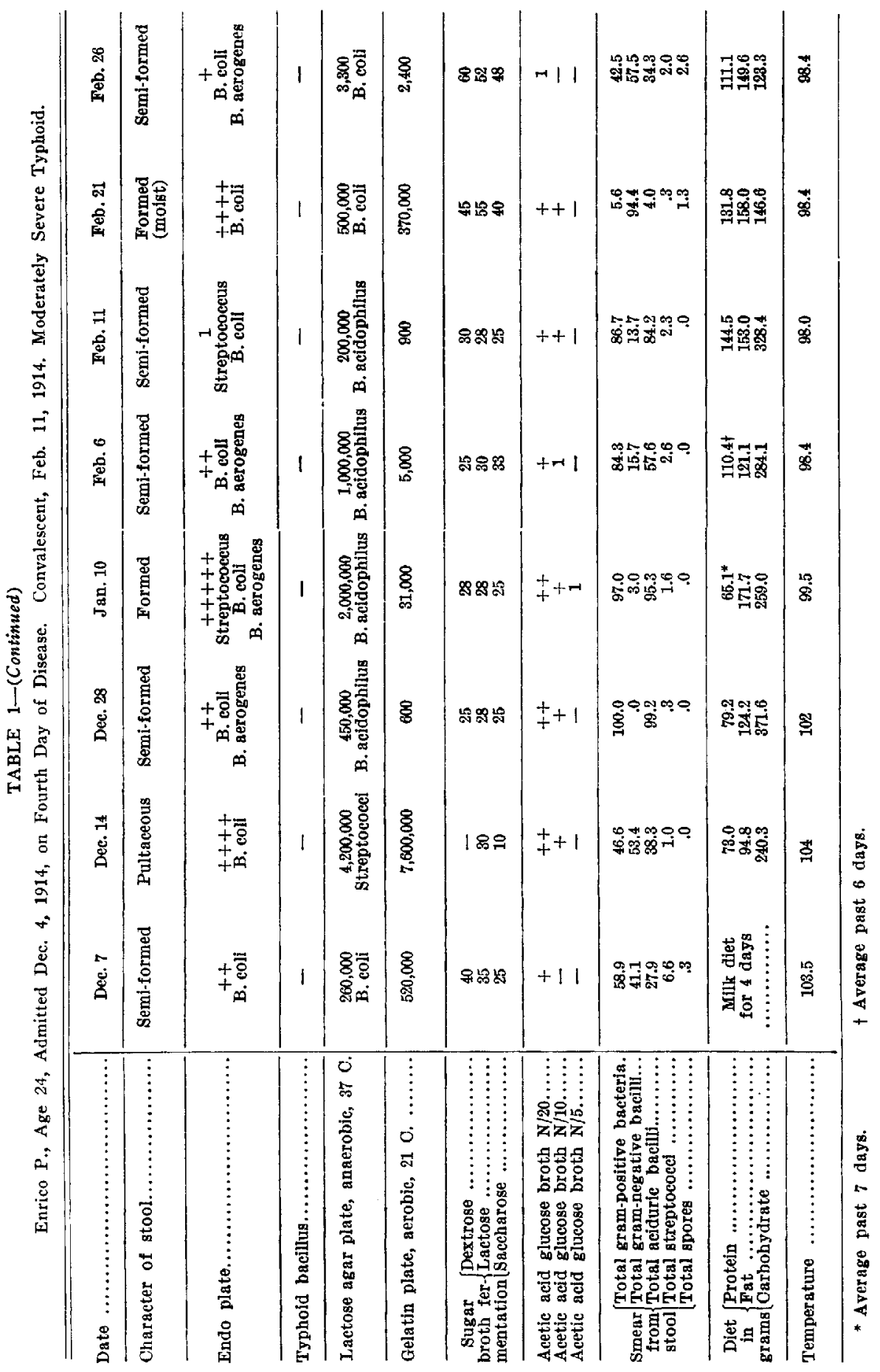

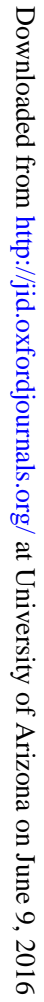


TABLE 2

Effect of High Cazory Diet on Intestinal Bacteria of Typhoid Patients with an Initial. FFrmentative Type of Flora

Anthony G., Age 18, Admitted Aug. 19, 1913, on Eleventh Day of Disease. Convalescent, Sept. 8, 1913. Mild Typhoid.

\begin{tabular}{|c|c|c|c|c|}
\hline Date $\ldots \ldots \ldots \ldots$ & Aug. 22 & Aug. 26 & Sept. 2 & Sept. 8 \\
\hline Character of stool................... & Pultaceous & Pultaceous & Pultaceous & Semj-formed \\
\hline Endo plate.............................. & $\begin{array}{l}+++ \\
\text { Streptococcus } \\
\text { B. coli } \\
\text { B. aerogenes }\end{array}$ & $\begin{array}{l}\text { B. coli } \\
\text { B. aerogenes } \\
\text { Streptococens } \\
\text { B. typhosus }\end{array}$ & $\begin{array}{l}\quad++++ \\
\text { B. coli } \\
\text { B. aerogenes } \\
\text { Streptococcus }\end{array}$ & $\begin{array}{c}\stackrel{++}{\text { B. coli }} \\
\text { Streptococcus } \\
\text { B, aerogenes }\end{array}$ \\
\hline Typhoid bacillus.................. & - & + & - & - \\
\hline Sugar-free agar plate, aerobic, 370. & 225,000 & 100,000 & 850,000 & 100,000 \\
\hline Lactose agar plate, anaeroble, $37 \mathrm{C}$. & $\begin{array}{l}\text { 1,450,000 } \\
\text { B. acidophilus }\end{array}$ & $\begin{array}{l}1,400,000 \\
\text { B. acidophllus }\end{array}$ & $\begin{array}{l}\text { 1,300,000 } \\
\text { B. acidophilus }\end{array}$ & $\begin{array}{l}1,350,000 \\
\text { B. acidophilus }\end{array}$ \\
\hline $\begin{array}{l}\text { Spores, aerobic, } 37 \mathrm{C}, \ldots \ldots \ldots \ldots \ldots \ldots \\
\text { Spores, anaeroble, } 37 \mathrm{c} . \ldots \ldots \ldots \ldots \ldots\end{array}$ & $\begin{array}{l}1 \\
0\end{array}$ & $\stackrel{0}{0}$ & $\begin{array}{l}1 \\
0\end{array}$ & $\begin{array}{l}0 \\
0\end{array}$ \\
\hline $\begin{array}{l}\text { Lactose bile fer-\{Gas } \ldots \ldots \ldots \ldots \ldots \ldots \\
\text { mentation tube Sediment } \ldots \ldots \ldots \ldots \ldots\end{array}$ & $\begin{array}{c}40 \\
\text { Peptolytic }\end{array}$ & $\stackrel{30}{30}$ Fermentative & $\stackrel{50}{\text { Fermentative }}$ & $\stackrel{45}{\text { Fermentative }}$ \\
\hline Gelatin stab, 21 C. ............... & + & + & + & - \\
\hline Loeffler serum slant, $37 \mathrm{C}, \ldots \ldots \ldots$ & ++ & \pm & \pm & \pm \\
\hline 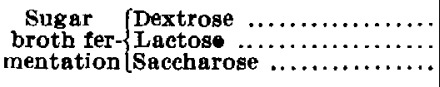 & $\begin{array}{l}30 \\
23 \\
28\end{array}$ & $\begin{array}{l}25 \\
28 \\
18\end{array}$ & $\begin{array}{l}38 \\
35 \\
25\end{array}$ & $\begin{array}{l}40 \\
45 \\
15\end{array}$ \\
\hline $\begin{array}{l}\text { Acetic acid glucose broth } \mathrm{N} / 20 \ldots \ldots \\
\text { Acetic acid glucose broth } \mathrm{N} / 10 \ldots \ldots \\
\text { Acetic acid glucose broth } \mathrm{N} / 5 \ldots \ldots \ldots\end{array}$ & $\begin{array}{c}++ \\
+ \\
+\end{array}$ & $\begin{array}{l}++ \\
+ \\
+\end{array}$ & $\begin{array}{l}++ \\
+ \\
+\end{array}$ & $\begin{array}{c}++ \\
+ \\
+\end{array}$ \\
\hline 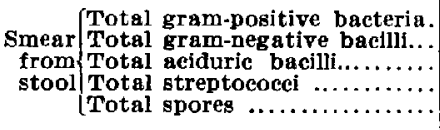 & $\begin{array}{r}66.0 \\
34.0 \\
62.2 \\
0.3 \\
0.0\end{array}$ & 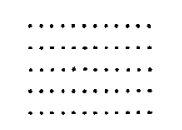 & $\begin{array}{r}100.0 \\
0.0 \\
98.6 \\
0.6 \\
0.0\end{array}$ & $\begin{array}{r}92.0 \\
8.0 \\
89.9 \\
1.0 \\
0.0\end{array}$ \\
\hline 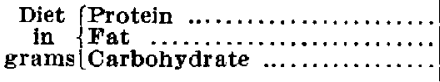 & $\begin{array}{l}\text { Milk diet } \\
\text { since } \\
\text { Aug. } 19\end{array}$ & $\begin{array}{r}44.2 \\
57.6 \\
149.9\end{array}$ & $\begin{array}{l}96.8^{*} \\
177.3 \\
359.5\end{array}$ & $\begin{array}{l}108.0 \\
212.3 \\
370.3\end{array}$ \\
\hline Temperature ... & 103.2 & 101.6 & 98.9 & 98.6 \\
\hline
\end{tabular}

* Average for 2 days. 
TABLE 2.-(Continued)

Christian M., Age 31, Admitted Sept. 8, 1913, on Eleventh Day of Disease. Convalescent, Sept. 23, 1913. Mild Typhoid.

\begin{tabular}{|c|c|c|c|c|}
\hline 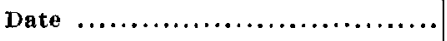 & Sept. 17 & Sept. 22 & Sept. 27 & Sept. 30 \\
\hline 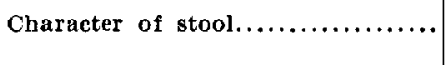 & Pultaceous & Formed & $\begin{array}{l}\text { Formed } \\
\text { (rather dry) }\end{array}$ & Pultaceous \\
\hline 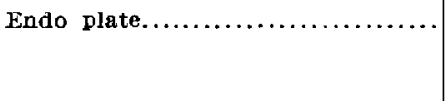 & $\begin{array}{c}+++t \\
\text { B. coll } \\
\text { Streptococcus } \\
\text { B. aerogenes }\end{array}$ & $\begin{array}{l}\quad++++ \\
\text { B. coli } \\
\text { Streptococeus } \\
\text { B. aerogenes }\end{array}$ & $\begin{array}{c}+++ \\
\text { Streptococcus } \\
\text { B. coli } \\
\text { Staphylococeus }\end{array}$ & $\begin{array}{l}+++++ \\
\text { Streptococcus } \\
\text { B. coli } \\
\text { B. paracoli }\end{array}$ \\
\hline Typhoid bacillus.................. & - & - & - & - \\
\hline Sugar-free agar plate, aerobic, $37 \mathrm{C}$. & 520000 & 325,000 & 56,000 & $1,100,000$ \\
\hline Lactose agar plate, angerobic, $37 \mathrm{C}$. & $\begin{array}{l}2,730,000 \\
\text { B. acidophilus }\end{array}$ & $\begin{array}{l}\mathbf{3}, 450,000 \\
\text { B. acidophilus }\end{array}$ & $\begin{array}{l}50,000 \\
\text { B. coll }\end{array}$ & $\begin{array}{l}4,100,000 \\
\text { B. acidophilus }\end{array}$ \\
\hline $\begin{array}{l}\text { Spores, aerobic, } 37 \underset{\mathrm{C}}{\mathrm{C}} \ldots \ldots \ldots \ldots \ldots \ldots \\
\text { Spores, anaerobic, } 37 \mathrm{C} \ldots \ldots \ldots \ldots \ldots\end{array}$ & $\begin{array}{l}0 \\
0\end{array}$ & $\begin{array}{l}0 \\
0\end{array}$ & $\begin{array}{l}7 \\
0\end{array}$ & $\begin{array}{l}0 \\
0\end{array}$ \\
\hline $\begin{array}{l}\text { Lactose bile fer-\{Gas } \ldots \ldots \ldots \ldots \ldots \ldots \\
\text { mentation tube } \ldots \text { Sediment } \ldots \ldots \ldots \ldots\end{array}$ & $\stackrel{33}{\text { Fermentative }}$ & $\stackrel{65}{\text { Fermentative }}$ & $\stackrel{75}{\text { Peptolytic }}$ & $\stackrel{48}{\text { Fermentative }}$ \\
\hline Gelatin stab, 21 C. $\ldots \ldots \ldots \ldots \ldots \ldots$ & + & ++ & + & +++ \\
\hline Loeffer serum slant, 37 C. ..... & \pm & \pm & ++ & ++ \\
\hline$\underset{\text { broth fer }}{\text { Sugar }}\left\{\begin{array}{l}\text { Dextrose } \ldots \ldots \ldots \ldots \ldots \ldots \ldots \ldots \\
\text { Lactose } \ldots \ldots \ldots \ldots \ldots \ldots \ldots\end{array}\right.$ & $\begin{array}{l}18 \\
20 \\
20\end{array}$ & $\begin{array}{l}18 \\
33 \\
10\end{array}$ & $\begin{array}{l}35 \\
45 \\
18\end{array}$ & $\begin{array}{l}12 \\
18 \\
10\end{array}$ \\
\hline $\begin{array}{l}\text { Acetic acid glucose broth } \mathbf{N} / 20 \ldots \ldots \\
\text { Acetic aeid glucose broth } \mathbf{N} / 10 \ldots \ldots \\
\text { Acetic acid glucose broth } \mathbf{N} / 5 \ldots \ldots\end{array}$ & $\begin{array}{l}++ \\
+ \\
+\end{array}$ & $\begin{array}{c}+t \\
++ \\
1\end{array}$ & $\frac{1}{-}$ & $\begin{array}{l}t+t \\
t+ \\
-\end{array}$ \\
\hline 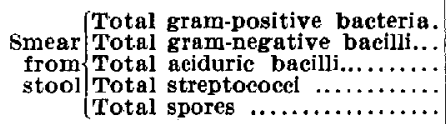 & $\begin{array}{r}52.0 \\
48.0 \\
48.6 \\
1.3 \\
0.0\end{array}$ & $\begin{array}{r}55.3 \\
44.7 \\
45.9 \\
1.3 \\
0.0\end{array}$ & $\begin{array}{r}86.6 \\
14.4 \\
63.2 \\
4.0 \\
0.0\end{array}$ & $\begin{array}{r}36.3 \\
63.6 \\
30.9 \\
2.6 \\
0.0\end{array}$ \\
\hline$\underset{\text { in }}{\text { Diet }}\left\{\begin{array}{l}\text { Protein } \ldots \ldots \ldots \ldots \ldots \ldots \ldots \ldots \ldots \ldots \\
\text { Fat } \ldots \ldots \ldots \ldots \ldots \ldots \ldots \ldots \ldots \\
\text { Carbohydrate } \ldots \ldots \ldots \ldots \ldots \ldots\end{array}\right.$ & $\begin{array}{l}80.5^{*} \\
122.1 \\
349.6\end{array}$ & $\begin{array}{r}94.1 \\
74.2 \\
483.4\end{array}$ & $\begin{array}{r}96.8 \\
206.5 \\
209.8\end{array}$ & $\begin{array}{l}111.8 \\
155.9 \\
457.6\end{array}$ \\
\hline Temperature $\ldots \ldots \ldots \ldots \ldots \ldots \ldots \ldots$ & 101.8 & 99.4 & 99.0 & 90.5 \\
\hline
\end{tabular}

* Average for 3 days. 
TABLE 2,- (Continued) Morris S., Age 25, Admitted Oct. 17, 1913, Seventh Day of Disease. $\begin{gathered}\text { Relapsed Nov. 15-Dec. 5, 1913; relap } \\ \text { Dec. 17-Dec. 25, 1913. Severe Typhoid. }\end{gathered}$

\begin{tabular}{|c|c|c|c|c|c|}
\hline 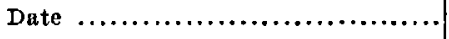 & Oet. 24 & Oet. 28 & Nov. 6 & Nov. 11 & Nov. 24 \\
\hline Character of stool................. & Fluid & Pultaceous & Seml-formed & $\begin{array}{l}\text { Pultaceous } \\
\text { (frothy) }\end{array}$ & Fluid \\
\hline 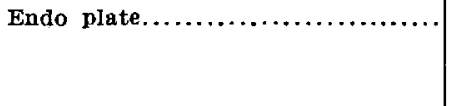 & $\underset{\text { Streptococcus }}{\stackrel{+}{\text { coll }}}$ & $\begin{array}{l}++ \\
\text { Streptococcus } \\
\text { B. coll } \\
\text { B. paracoli }\end{array}$ & $\begin{array}{l}++++ \\
\text { B. coll }\end{array}$ & B. coll & $\begin{array}{c}++ \\
\text { B. gerogen } \\
\text { B. coli } \\
\text { Streptocoed }\end{array}$ \\
\hline Typhoid bacillus...................... & - & $+^{*}$ & $+*$ & - & - \\
\hline Sugar-free agar plate, aeroble, $37 \mathrm{C}$. & 16,000 & 100,000 & 520,000 & 48,000 & 250,000 \\
\hline Lactose agar plate, anaerobic, $37 \mathrm{C}$. & $\begin{array}{l}1,200,000 \\
\text { B. acidophilus }\end{array}$ & $\begin{array}{l}1,800000 \\
\text { B. aeidophilus }\end{array}$ & $\begin{array}{l}6,800,000 \\
\text { B. acidophllus }\end{array}$ & $\begin{array}{l}1,800,000 \\
\text { B. acidophilus }\end{array}$ & $\begin{array}{r}1,170,000 \\
\text { B. acidophi }\end{array}$ \\
\hline $\begin{array}{l}\text { Spores, aerobic, 37 } \mathrm{C} . \ldots \ldots \ldots \ldots \ldots \\
\text { Spores, anaerobic, } 37 \mathrm{C}, \ldots \ldots \ldots \ldots \ldots\end{array}$ & $\stackrel{0}{0}$ & $\begin{array}{l}5 \\
0\end{array}$ & $\begin{array}{l}0 \\
0\end{array}$ & $\begin{array}{l}0 \\
0\end{array}$ & $\begin{array}{l}1 \\
1\end{array}$ \\
\hline $\begin{array}{c}\text { Lactose bile fer-\{ }\left\{\begin{array}{l}\text { Gas } \\
\text { mentation tube }\end{array} \text { Sediment } \ldots \ldots \ldots \ldots \ldots\right. \\
\ldots\end{array}$ & $\stackrel{66}{\text { Fermentative }}$ & $\stackrel{75}{\text { Fermentative }}$ & $\stackrel{75}{\text { Fermentative }}$ & $\begin{array}{c}75 \\
\text { Fermentative }\end{array}$ & Fermentat \\
\hline Gelatin stab, $210 . \ldots \ldots \ldots \ldots \ldots$ & \pm & + & \pm & ++ & \pm \\
\hline Loeffler serum slant, 37 C. .......... & +++ & ++ & ++ & + & \pm \\
\hline 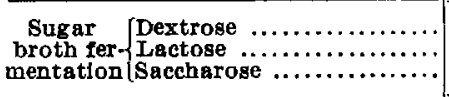 & $\begin{array}{r}20 \\
18 \\
2\end{array}$ & $\begin{array}{l}65 \\
32 \\
10\end{array}$ & $\begin{array}{r}20 \\
20 \\
5\end{array}$ & $\begin{array}{l}16 \\
22 \\
28\end{array}$ & $\begin{array}{r}28 \\
18 \\
8\end{array}$ \\
\hline $\begin{array}{l}\text { Acetic acid glucose broth } \mathbf{N} / 20 \ldots \ldots \\
\text { Acetic acld glucose broth } \mathbf{N} / 10 \ldots \ldots \\
\text { Acetic acld glucose broth } \mathbf{N} / 5 \ldots \ldots\end{array}$ & $\begin{array}{c}+++ \\
+++ \\
++\end{array}$ & $\begin{array}{c}+++ \\
++ \\
+\end{array}$ & $\begin{array}{c}+++ \\
++ \\
++\end{array}$ & $\stackrel{++}{+}$ & $\begin{array}{c}++++ \\
+++ \\
1\end{array}$ \\
\hline 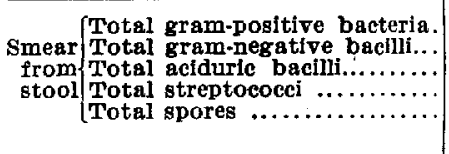 & $\begin{array}{r}74.3 \\
25.7 \\
64.1 \\
2.6 \\
0.0\end{array}$ & $\begin{array}{c}85.7 \\
14.3 \\
75.6 \\
6.0 \\
0.0 \\
\text { (Many yeasts) }\end{array}$ & $\begin{array}{r}58.4 \\
41.6 \\
52.2 \\
1.6 \\
0.0\end{array}$ & $\begin{array}{c}88.0 \\
12.0 \\
85.6 \\
0.0 \\
0.0 \\
\text { (Many yeasts) }\end{array}$ & $\begin{array}{r}85.7 \\
14.3 \\
84.2 \\
0.6 \\
0.0\end{array}$ \\
\hline 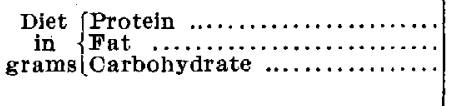 & $\begin{array}{l}\text { Oct. } 21-24 . \\
2,000-3,000 \text { calo- } \\
\text { ries with high } \\
\text { carbohydrate }\end{array}$ & $\begin{array}{r}109.8 \\
80.9 \\
324.9\end{array}$ & $\begin{array}{r}95.1 \\
129.9 \\
295.9\end{array}$ & $\begin{array}{r}95.4 \\
143.3 \\
319.1\end{array}$ & $\begin{array}{r}59.9 \\
107.9 \\
203.1\end{array}$ \\
\hline Temperature $\quad \ldots . \ldots \ldots \ldots \ldots \ldots \ldots . . . . .$. & 103 & 108.5 & 102 & 99.5 & 104 \\
\hline
\end{tabular}

* See Page 34. 


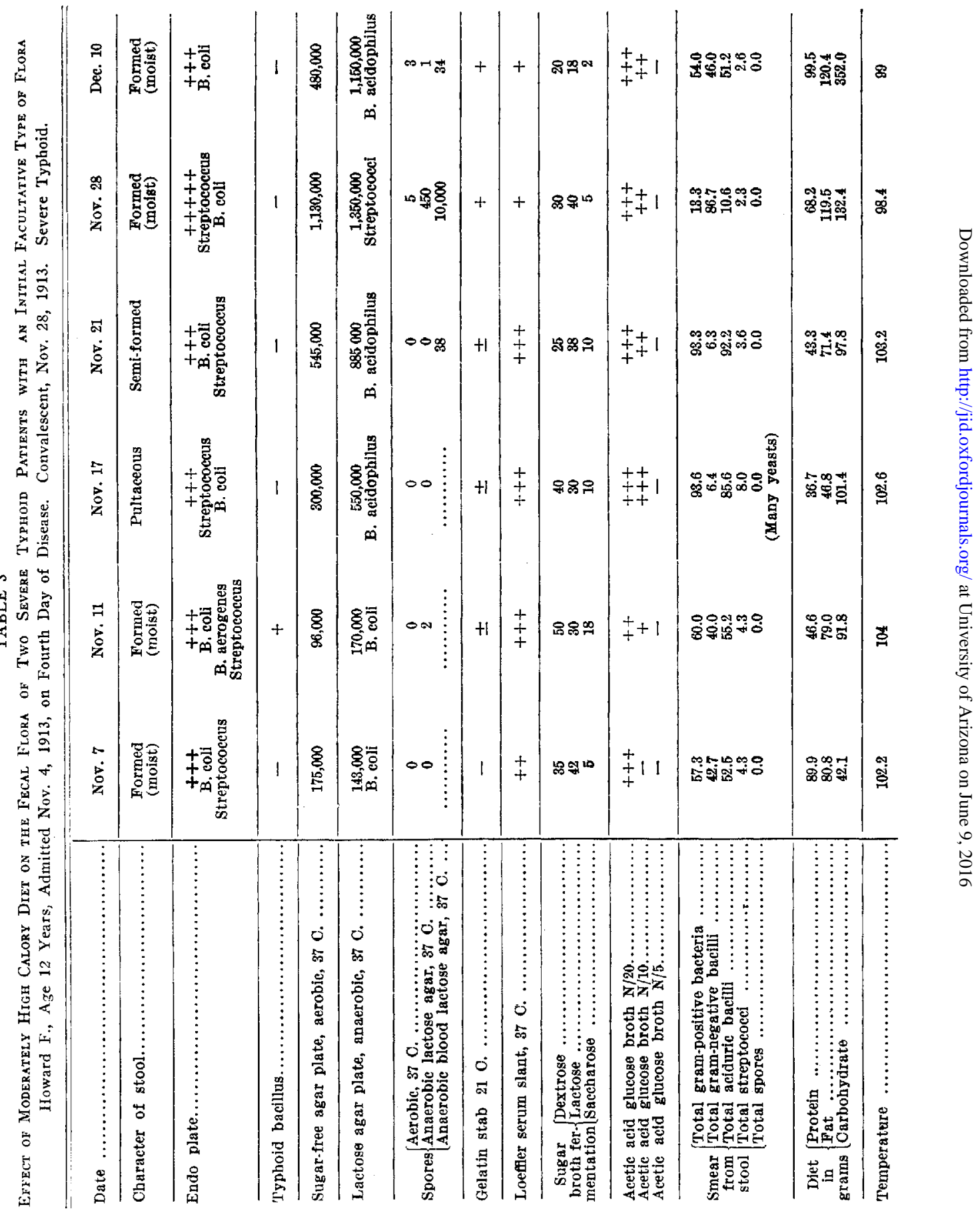




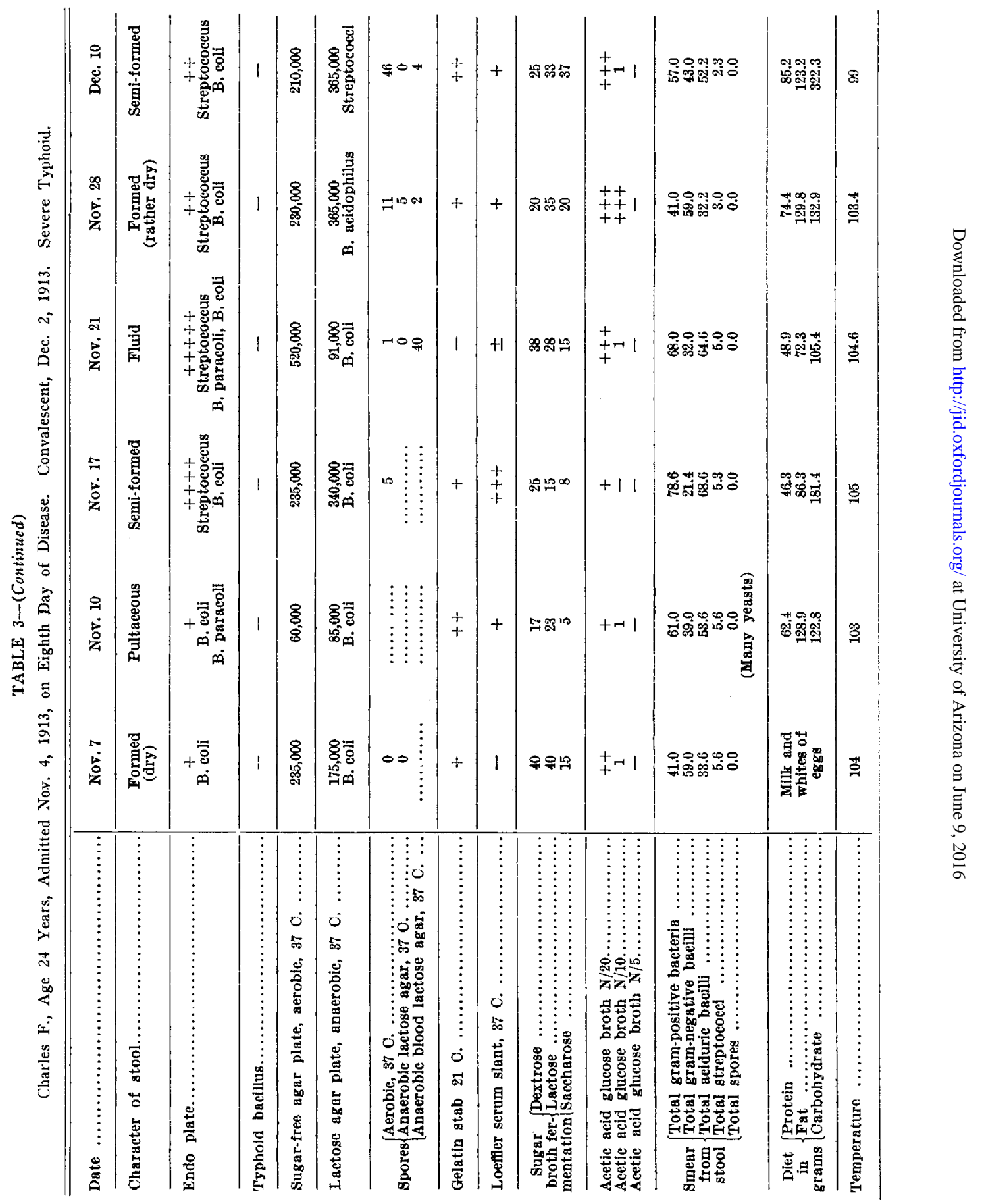


TABLE 4

Typioid Cases with an Initial Putrefactive Flora

Thomas F., Age 34, Admitted Aug. 22, 1913, on Fourth Day of Disease. Convalescent, Oct. $2,1913$. Severe Typhoid.

\begin{tabular}{|c|c|c|c|c|c|}
\hline Date $\ldots \ldots \ldots \ldots \ldots \ldots \ldots \ldots \ldots \ldots \ldots$ & Aug. 26 & Aug. 29 & Sept. 4 & Sept. 13 & Sept. 19 \\
\hline Character of stool................. & $\begin{array}{l}\text { Formed } \\
\text { (moist) }\end{array}$ & Pultaceous & Semi-fluid & Pultaceous & Pultaceous \\
\hline 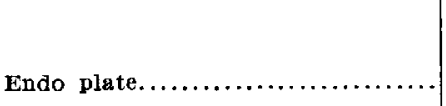 & $\begin{array}{c}\underset{++}{\text { B. coli }} \\
\text { Streptococcus } \\
\text { B. pyocy aneus }\end{array}$ & $\begin{array}{l}\text { B. cofi } \\
\text { Streptococcus } \\
\text { B. gerogenes }\end{array}$ & $\begin{array}{c}+++ \\
\text { B. coll } \\
\text { Btreptococeus } \\
\text { B. aerogenes }\end{array}$ & $\begin{array}{l}+++ \\
\text { B. coli } \\
\text { Streptococcus } \\
\text { B. typhosus }\end{array}$ & $\begin{array}{l}\text { +t } \\
\text { B. typhosus } \\
\text { B. alkaligenes } \\
\text { B. coli }\end{array}$ \\
\hline Typhoid bacillus................... & - & 一 & - & + & + \\
\hline Sugar-free agar plate, aerobic, $37 \mathrm{C}$. & 160,000 & 730,000 & 290,000 & 700,000 & 130,000 \\
\hline Lactose agar plate, anaerobic, 370. & $\begin{array}{l}180,000 \\
\text { B. coli }\end{array}$ & $\begin{array}{c}1,450,000 \\
\text { Streptocoeci }\end{array}$ & $\begin{array}{l}215,000 \\
\text { B. coll }\end{array}$ & $\begin{array}{l}900,000 \\
\text { B. coli }\end{array}$ & $\begin{array}{l}162,000 \\
\text { B. acidophilus }\end{array}$ \\
\hline $\begin{array}{l}\text { Spores, aerobic, } 37 \text { C } \ldots \ldots \ldots \ldots \ldots \ldots \\
\text { Spores, angerobic, } 37 \text {. } \ldots \ldots \ldots \ldots \ldots\end{array}$ & 56 & $\begin{array}{l}0 \\
0\end{array}$ & $\begin{array}{r}625 \\
0\end{array}$ & $\begin{array}{l}0 \\
0\end{array}$ & $\begin{array}{l}2 \\
0\end{array}$ \\
\hline $\begin{array}{l}\text { T.actose blle fer-\{Gas } \ldots \ldots \ldots \ldots \ldots \ldots \\
\text { mentation tube }\left\{\begin{array}{l}\text { Sediment } \\
\ldots\end{array} \ldots \ldots \ldots\right.\end{array}$ & $\begin{array}{c}60 \\
\text { Putrefactive }\end{array}$ & $\begin{array}{c}18 \\
\ldots \ldots \ldots\end{array}$ & $\stackrel{42}{\text { Peptolytic }}$ & $\stackrel{35}{\text { Peptolytie }}$ & $\begin{array}{l}50 \\
\text { Peptolytic }\end{array}$ \\
\hline Gelatin stab, 21 o. $\ldots \ldots \ldots \ldots \ldots \ldots$ & $+++t$ & \pm & $+t+$ & \pm & ++ \\
\hline Loeffler serum medium, $37 \mathrm{C}, \ldots \ldots \ldots$ & ++++ & ++ & +++ & +++ & $+t++$ \\
\hline 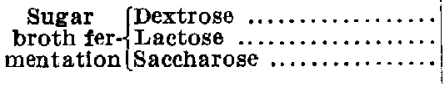 & $\begin{array}{l}25 \\
30 \\
20\end{array}$ & $\begin{array}{l}35 \\
25 \\
12\end{array}$ & $\begin{array}{l}20 \\
35 \\
15\end{array}$ & $\begin{array}{l}30 \\
28 \\
15\end{array}$ & $\begin{array}{l}48 \\
30 \\
12\end{array}$ \\
\hline $\begin{array}{l}\text { Acetic acid glucose broth } \mathbf{N} / 20 \ldots \ldots \\
\text { Acetic acid glucose broth } \mathbf{N} / 10 \ldots \ldots \\
\text { Acetic acid glucose broth } \mathbf{N} / 5 \ldots \ldots \ldots\end{array}$ & E & $\stackrel{+}{1}$ & $\stackrel{+}{-}$ & $\underline{+}$ & $\begin{array}{l}+ \\
+ \\
+\end{array}$ \\
\hline $\begin{array}{l}\text { Total gram-positive bacteria } \ldots \ldots \ldots \ldots \\
\text { Total gram-negative bacilli } \ldots \ldots \ldots \ldots \\
\text { Total aciduric bacilli } \ldots \ldots \ldots \ldots \ldots \ldots \ldots \\
\text { Total streptococei } \ldots \ldots \ldots \ldots \ldots \ldots \ldots \ldots \\
\text { Total spores } \ldots \ldots \ldots \ldots \ldots \ldots \ldots \ldots \ldots\end{array}$ & $\begin{array}{r}16.3 \\
83.7 \\
14.2 \\
1.3 \\
0.0\end{array}$ & $\begin{array}{r}69.3 \\
30.7 \\
29.6 \\
7.6 \\
2.3\end{array}$ & $\begin{array}{r}49.3 \\
50.7 \\
42.3 \\
2.3 \\
0.0\end{array}$ & $\begin{array}{r}59.3 \\
40.7 \\
63.6 \\
2.6 \\
0.0\end{array}$ & $\begin{array}{r}27.6 \\
72.4 \\
25.2 \\
2.6 \\
0.0\end{array}$ \\
\hline$\underset{\text { in }}{\text { Dlet }}\left\{\begin{array}{l}\text { Protein } \ldots \ldots \ldots \ldots \ldots \ldots \ldots \ldots \ldots \\
\text { Frams } \ldots \ldots \ldots \ldots \ldots \ldots \ldots \ldots \ldots\end{array}\right.$ & $\begin{array}{l}\text { Milk } \\
\text { since } \\
\text { Aug. } 22\end{array}$ & $\begin{array}{r}48.4 \\
78.6 \\
135.6\end{array}$ & $\begin{array}{r}50.1 \\
71.6 \\
144.7\end{array}$ & $\begin{array}{r}84.4 \\
159.2 \\
260.6\end{array}$ & $\begin{array}{r}94.8 \\
178.1 \\
480.6\end{array}$ \\
\hline Temperature $\ldots \ldots \ldots \ldots \ldots \ldots \ldots \ldots$ & 105 & 104.6 & 103 & 100 & 100.5 \\
\hline
\end{tabular}


TABLE 4.-(Continued)

James C., Age 52, Admitted Aug. 24, 1913, on Seventeenth Day of Disease. Died Aug. 29, 1913. Emil C. Age 23, Admitted Aug. 23, 1913, on Fifth Day of Disease. Convalescent, Oct. 17, 1913. Severe Typhoid.

\begin{tabular}{|c|c|c|c|c|c|}
\hline Date $\ldots \ldots \ldots \ldots \ldots \ldots \ldots \ldots \ldots \ldots \ldots \ldots \ldots \ldots \ldots$ & $\begin{array}{l}\text { James } 0 . \\
\text { Aug. } 25\end{array}$ & Sept. 6 & Sept. $16^{\text {Emi }}$ & 10. Sept. 22 & Oct. 6 \\
\hline Character of stool..................... & Semi-fluid & Pultaceous & $\begin{array}{l}\text { Formed } \\
\text { (moist) }\end{array}$ & Pultaceous & $\begin{array}{l}\text { Formed } \\
\text { (rather dry) }\end{array}$ \\
\hline Endo plate....................... & $\begin{array}{l}\text { B. coll } \\
\text { B. typhosus } \\
\text { Streptococeus }\end{array}$ & $\begin{array}{c}\stackrel{++}{++} \\
\text { B. coll } \\
\text { Btreptococcus } \\
\text { B. aerogenes }\end{array}$ & $\begin{array}{l}\stackrel{++}{++} \\
\text { B. coll } \\
\text { Streptogenes } \\
\text { atrocens }\end{array}$ & $\begin{array}{l}\stackrel{++++}{\text { B. coli }} \\
\text { Streptococcus } \\
\text { B. aerogenes }\end{array}$ & $\underset{\text { B. coli }}{++++}$ \\
\hline Typhoid bacillus....................... & + & - & - & - & $+^{*}$ \\
\hline Sugar-free agar plate, aerobic, $37 \mathrm{C}$. & 52,000 & 520,000 & 145,000 & 730,000 & 845,000 \\
\hline Lactose agar plate, anaeroblc, 370 & $\begin{array}{l}53,000 \\
\text { B. coli }\end{array}$ & $\begin{array}{l}580,000 \\
\text { B. coli }\end{array}$ & $\begin{array}{l}160000 \\
\text { B. coll }\end{array}$ & $\begin{array}{l}520,000 \\
\text { B. coll }\end{array}$ & $\begin{array}{l}660,000 \\
\text { B. coli }\end{array}$ \\
\hline $\begin{array}{l}\text { Spores, aerobic, } 37 \text { } 0 . \ldots \ldots \ldots \ldots \ldots \ldots \\
\text { Spores, anaerobic, } 37 \mathrm{c}, \ldots \ldots \ldots \ldots \ldots\end{array}$ & $\begin{array}{r}0 \\
85\end{array}$ & $\stackrel{0}{2}$ & $\begin{array}{r}280 \\
20\end{array}$ & $\begin{array}{r}20 \\
0\end{array}$ & $\begin{array}{l}33 \\
35\end{array}$ \\
\hline $\begin{array}{l}\text { Lactose bile fer-\{Gas } \ldots \ldots \ldots \ldots \ldots \ldots \ldots \\
\text { mentation tube }\{\text { Sediment } \ldots \ldots \ldots \ldots\end{array}$ & $\begin{array}{c}65 \\
\text { Peptolytie }\end{array}$ & $\begin{array}{c}60 \\
\text { Putrefactive }\end{array}$ & $\begin{array}{l}38 \\
\text { Putrefactive }\end{array}$ & $\begin{array}{l}70 \\
\text { Peptolytic }\end{array}$ & \\
\hline Gelatín stab, $210 . \ldots \ldots \ldots \ldots \ldots \ldots$ & $++t$ & \pm & \pm & \pm & \pm \\
\hline Loeffler serum medium, $370 . \ldots \ldots$. & ++ & \pm & + & +++ & ++ \\
\hline 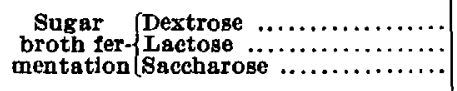 & $\begin{array}{l}40 \\
35 \\
25\end{array}$ & $\begin{array}{l}40 \\
20 \\
15\end{array}$ & $\begin{array}{l}20 \\
25 \\
25\end{array}$ & $\begin{array}{l}30 \\
60 \\
38\end{array}$ & $\begin{array}{l}40 \\
40 \\
10\end{array}$ \\
\hline $\begin{array}{l}\text { Acetic acid glucose broth } N / 20 \ldots \ldots \\
\text { Acetlc acid glucose broth } N / 10 \ldots \ldots \\
\text { Acetic acid glucose broth } N / 5 \ldots \ldots \ldots\end{array}$ & $\bar{z}$ & \pm & \pm & $\stackrel{++}{-}$ & $\frac{++}{-}$ \\
\hline 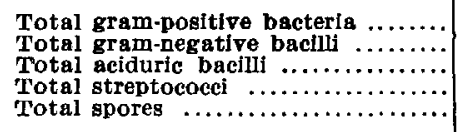 & $\begin{array}{r}48.0 \\
52.0 \\
10.6 \\
2.1 \\
0.0\end{array}$ & $\begin{array}{r}42.6 \\
57.4 \\
30.6 \\
2.1 \\
0.0\end{array}$ & $\begin{array}{r}50.0 \\
50.0 \\
41,9 \\
1.3 \\
0.0\end{array}$ & $\begin{array}{r}17.3 \\
82.6 \\
17.3 \\
0.0 \\
0.0\end{array}$ & $\begin{array}{r}26.0 \\
74.0 \\
20.9 \\
5.0 \\
0.0\end{array}$ \\
\hline 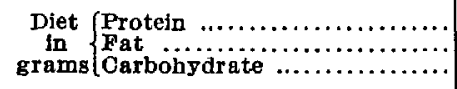 & Milk & $\underset{\text { (Iargely) }}{\text { Milk }}$ & $\begin{array}{l}92.6 \dagger \\
210.2 \\
161.6\end{array}$ & $\begin{array}{r}98.9 \dagger \\
73.7 \\
483.0\end{array}$ & $\begin{array}{r}86.5 \\
147.4 \\
300.2\end{array}$ \\
\hline Temperature $\ldots \ldots \ldots \ldots \ldots \ldots \ldots \ldots$ & 104.5 & 104.5 & 102 & 100 & 103 \\
\hline
\end{tabular}




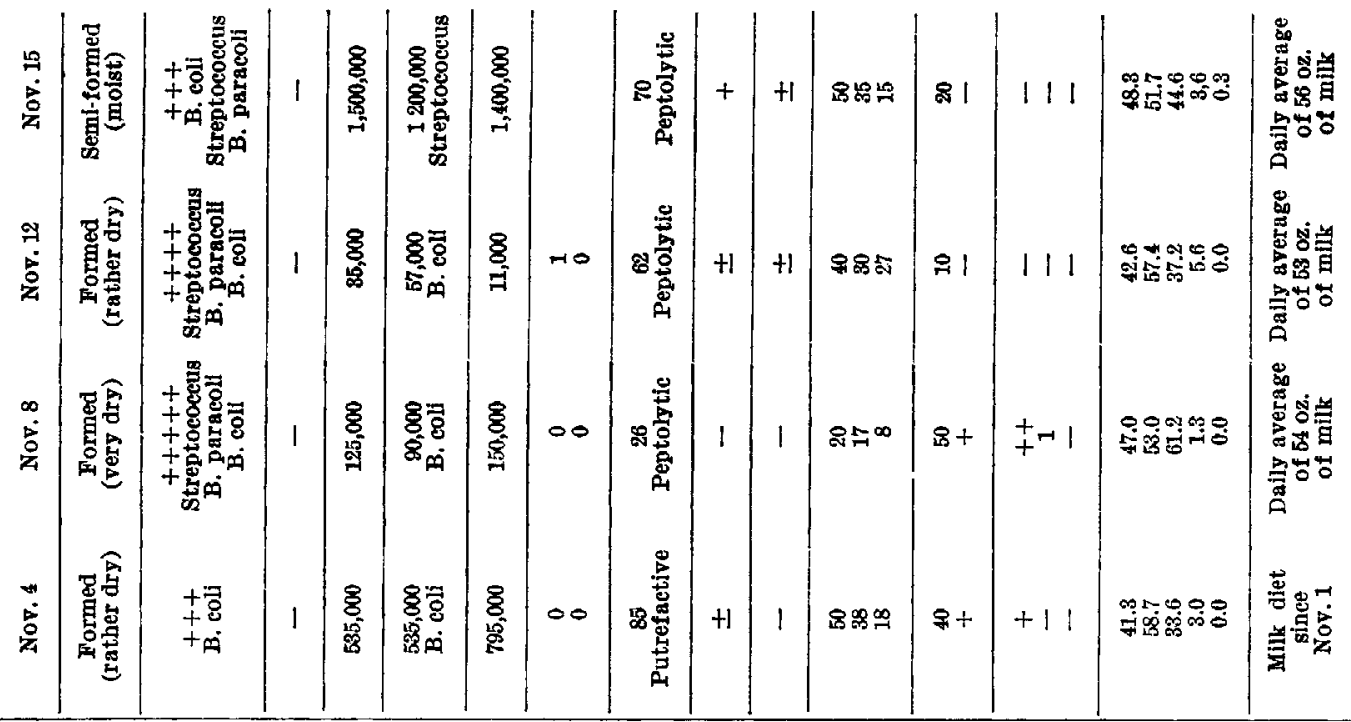

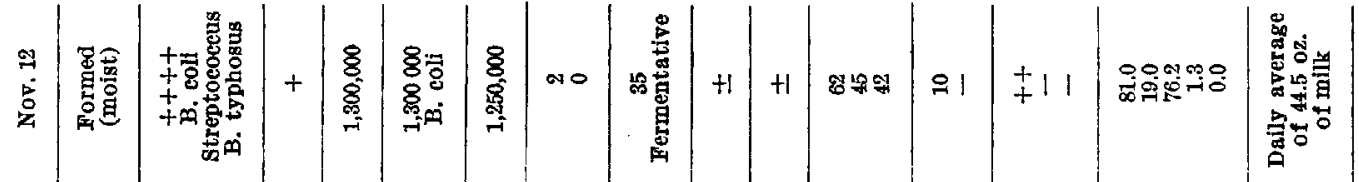

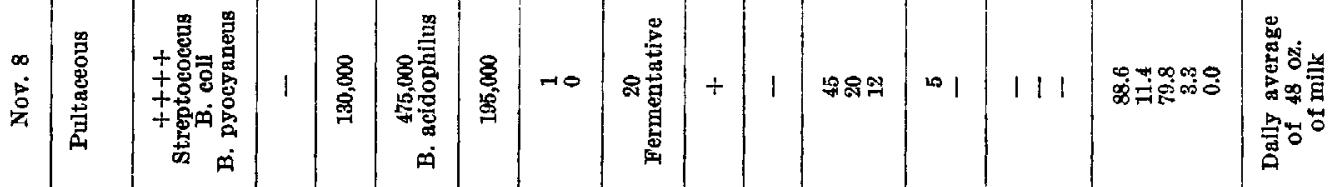

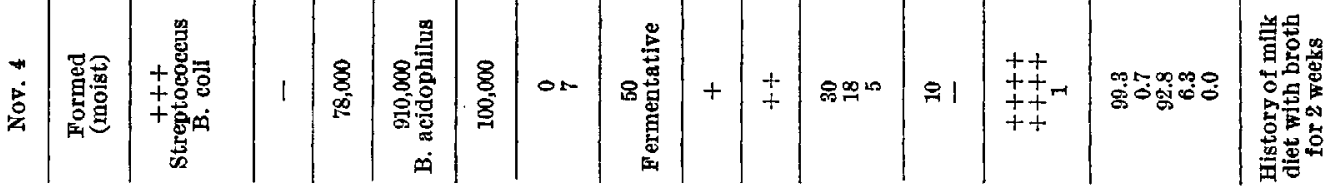

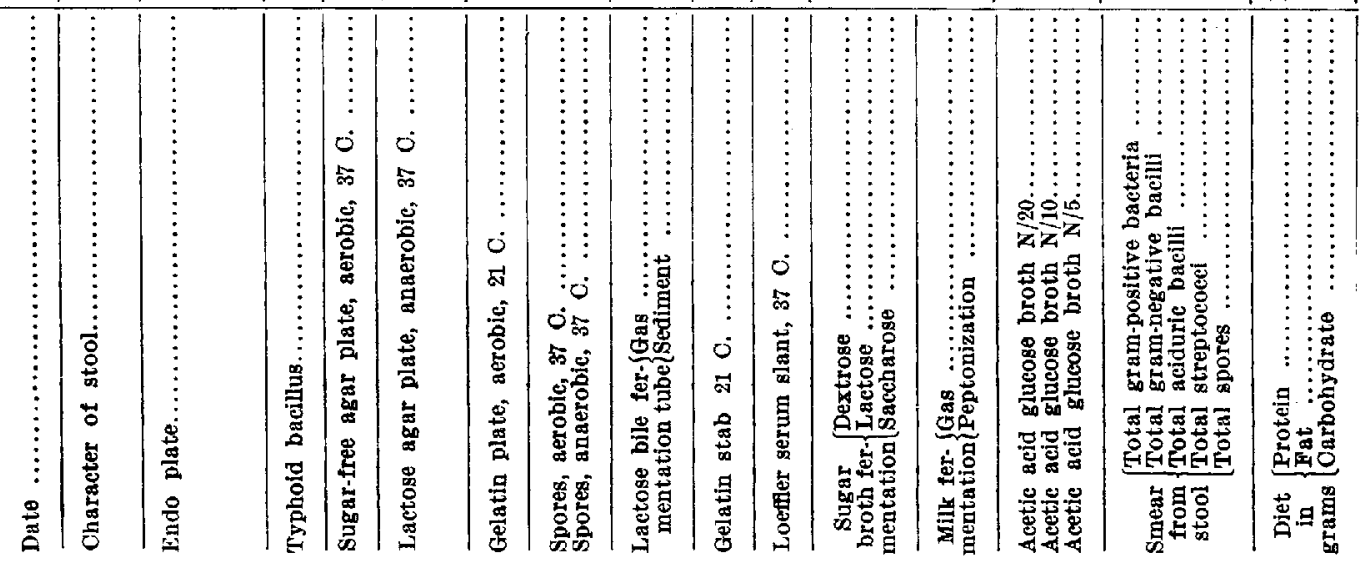




\section{GENERAL OBSERVATIONS}

Aside from general observations in regard to the various types of intestinal flora which one may find associated with infection by the typhoid bacillus, several problems of a more special nature have been considered during the course of this investigation: How readily and to what degree can a typhoidal fecal flora be changed in character in response to variations in the constitution of the diet? Do patients with a particular type of fecal flora tolerate with special facility the high calory diet containing large amounts of carbohydrate? What is the effect of liberal amounts of carbohydrate on the intestinal bacteria? What effect has a diet containing much fat on the fecal flora? May an initial unfavorable fecal flora be changed to a favorable type through the use of an appropriate diet? Do patients with an initial favorable type of fecal flora exhibit, on the average, an enhanced resistance to the typical course of typhoid fever?

In respect to some of these points, the evidence has been definite, whereas for others the amount of material has been sufficient to offer no more than suggestions which will be followed out as far as possible in subsequent work.

Before entering upon a discussion of these questions, it is well to review briefly the nature of the intestinal bacterial conditions, as revealed by an examination of the stools, which conditions may be encountered in man after the period of early adolescence. One may find a flora of marked fermentative propensities. In such cases there is a persistence, in a somewhat modified form, of the flora frequently encountered in normal childhood. Bacteria of the bacillus acidophilus type are present in large numbers and may even be the dominant organisms encountered in an examination of the stools. These bacilli utilize little protein in their metabolism, but split many carbohydrates actively with the formation of much lactic acid and without gas production. Associated with these aciduric bacteria are bacilli of the colon groutp and moderate numbers of streptococci. There are few or no, spores to be seen in gram-stained smears, in which the majority of the organisms are positive to the stain, and few, or no, putrefactive bacteria are revealed by cultural tests. Strong growths occur in the acetic acid glucose broth tubes, while the liquefying action on gelatin is generally moderate, and on Loeffler serum medium is slight. The best single indicator of such a flora is the appearance of the anaerobic lactose agar plates of the peculiar clusters of colonies with a clouding of the medium, which has been described in detail in the preceding section. The persistenee of such a purely fermentative flora is probably comparatively rare in adults on the ordinary mixed diet, but, on the other hand, adult individuals, in whom such a flora may be established through a diet for a brief period of large amounts of carbohydrate with reduced proportions of fat and protein, are not infrequently encotintered. Examples of such a fermentative flora are detailed in Table 2.

At the other extreme, we find individuals who harbor an obligate putrefactive intestinal flora. In such a flora, the aciduric types are absent, the colon 
bacilli are reduced in numbers, and the dominant organisms are a variety of anaerobic bacteria, many of which are spore bearing and all of which are either proteolytic or peptolytic. Streptococci and single cocci may be present in large numbers. As contrasted with a fermentative type, a putrefactive flora is notable for the markedly greater variety of bacterial species. In a cultural examination of such stools, no growth occurs in the acid broth tubes, gelatin and solidified serum are generally rapidly liquefied, and many colonies appear on anderobic plates seeded from a suitable dilution of the heated emulsion of the feces. Such a flora, as Distaso ${ }^{16}$ has pointed out, is commonly found among persons subject to chronic constipation associated with intestinal stasis.

Between these two extremes are all gradations of which we may designate the central type as "facultative." In the typical facultative flora, the dominant organisms are bacilli of the colon type and the majority of bacteria in a direct smear from the feces are negative to the gram stain. The aciduric bacteria are present, but in small numbers, and the same is true of spore-bearing bacilli. Liquefying types and coccal forms may be fairly well represented. Such a flora is called "facultative" because the dominant bacteria may act either in a fermentative or a putrefactive manner in response to the conditions in the intestinal tract and the nature of the pabulum offered them. As has been demonstrated by Kendall and his co-workers, ${ }^{17}$ bacilli of the colon and proteus groups, in the presence of a suitable carbohydrate, attack the sugar in preference to the protein that may be present in the medium, but, in the absence of carbohydrate, members of these and other groups become peptolytic and may give rise to indol and other supposedly toxic bodies. The intestinal bacterial conditions in the majority of the typhoid cases investigated soon after entrance into the hospital were of this facultative type, in some instances verging strongly toward the putrefactive type (Table 4). In fact, the great majority of adults in ordinarily good health will be found to harbor such floras.

These rather well-known facts in regard to the various types of intestinal flora have been reviewed because they have an important bearing on the nature of the changes in the numbers and types of the bacteria which followed the use of various diets.

All of these typhoid patients, when placed on the high calory diet, were given at first comparatively large amounts of carbohydrate often in considerable measure in the form of lactose, together with much smaller amounts of fat and protein. As has been observed, it might be anticipated that this preponderance of carbohydrate in the diet would exert a sparing action on the bacterial protein metabolism and would tend to convert the intestinal flora to a purely fermentative type. The change was well marked in certain cases and less so in others; the degree of substitution depended largely on the type of flora which was present at the initiation of the attack. From time to time, the proportions of the fat and carbohydrate, and to a less. degree of the protein, were varied and the effect on the flora noted

16. Centralbl. f. Bakteriol., Abt. 1, O., 1912, 62, p. 432 .

17. Jour. Am, Chem. Soc., 1913, 35, p. 1201. 
The studies of Herter and Kendall, ${ }^{5}$ on the changes in the intestinal flora of monkeys in response to various diets, were the first attempts in the determination the nature and degree of the substitution of bacterial types induced by abrupt variations in the chemical composition of the food. In these experi. ments, the animals were fed for one or two weeks on a diet consisting almost entirely of protein and then shifted abruptly to a diet consisting very largely of carbohydrate. On the protein diet the flora consisted largely of grampositive proteolytic or peptolytic bacteria, many of them spore bearing, also many of the colon and coccal types. After a few days of feeding with the carbohydrate diet, this markedly putrefactive flora underwent a rapid change to one of a fermentative type, resembling strikingly that of a human nursling in the predominance of the bacillus acidophilus and the bacillus bifidus types. The change of flora apparently was mainly due to the influence of the carbohydrate. Recently Rettger and Horton $^{18}$ have published a somewhat similar study with white rats as the subjects. The intestinal floras of rats on an ordinary mixed diet were compared with the flora of rats on a special diet, which was being used in nutrition experiments by Osborne and Mendel and which consisted of a pure protein (18 percent), protein-free milk (28 percent), starch (29 percent), and lard (25 percent). On the special diet, the flora became simplified and consisted largely of gram-positive bacteria of the acidophilus and bifidus groups with a reduction in the number of colon bacilli.

Bacteriological studies of this character have been extended to man only in a very few instances. Herter ${ }^{3}$ observed that, after the addition of 100 $200 \mathrm{gm}$. of cane sugar daily to the ordinary mixed diet of an adult normal human subject, the feces became soft, acid in reaction and odor, and the numbers of bacteria of the acidophilus type increased. MacNeal and his associates conducted an elaborate study of the bacterial elements in the stools of twelve normal adults placed on a definite, weighed diet, but apparently no attempt was made to correlate changes in the flora with chemical variations in the food administered. Kendall has recently attempted to change the "obligate dysentery flora" of infants, consisting of the bacillus dysenteriae, the bacillus coli, and streptococcus, which is potentially putrefactive, to one of a purely fermentative type through the feeding of lactose. In his favorable cases, he noted a gradual disappearance of these gram-negative forms and of streptococci assoated with the gradual appearance of the bacillus bifidus and the bacillus acidophilus.

\section{DISCUSSION OF CASES}

In Table 1 are detailed the changes in bacterial types which may occur as the result of liberal carbohydrate feeding in typhoidal patients with an initial favorable "facultative" intestinal flora. In these and certain other patients, the first bacterial response to a diet of 2,000-3,000 calories with the carbohydrate portion amounting to 250-300 gm. was a great increase in the numbers of colon bacilli or streptococci, or, in some instances, of both types. Within two weeks, however, the bacillus acidophilus had increased enormously until, in one case, it apparently outnumbered other viable bacteria about 500 to 1. This marked increase of the bacillus acidophilus is shown, not

18. Centralbl. f. Bakteriol., Abt. 1, O., 1914, 73, p. 362. 
only by a comparison of the counts from the anaerobic lactose agar plates with those from the aerobic gelatin or sugar-free agar plates, but also by the vigorous growths obtained in the acetic acid glucose broth tubes and by the direct counts from the gram-stained fecal smears. With both the patients (John T. and Enrico P.) these smears had become markedly gram-positive within two weeks and 97 percent of the bacteria seen were of the acidophilus type (John T. and Enrico P., Table 1). In the case of Enrico P., an examination of the sediment f:om the lactose broth fermentation tube showed that the bacillus bifidus was well represented in the stools, and it is possible that some of the bacteria classified as B. acidophilus in the count from the fecal smear were actually B. bifidus without the swollen or bifid end. The results with these patients prove that, even in adults and in conjunction with an inflammatory condition of the intestinal tract, the flora may be changed through a liberal carbohydrate diet to such a degree that, in many respects, it closely resembles the fermentative and comparatively non-gas-producing flora of the nursling.

In this series of cases, there was none exhibiting in the first examinations a putrefactive flora of the extreme type. There were, however, several examples of a fairly marked putrefactive type, observations on three of which are detailed in Table 4. Such of those cases as were examined soon after admission to the hospital did not reveal the presence of the bacillus acidophilus in the stools; on the other hand, bacteria liquefying gelatin and Loeffler's serum medium were apparently abundant, the sediments in the lactose bile fermentation tubes were putrefactive in type and a comparatively large number of spores developed on the anaerobic lactose agar plates. One of these patients (James C.) died soon after admission to the hospital and another (Thomas F.) could not be placed on more than a moderately high calory diet during the first two weeks in the hospital. As the amount of carbohydrate was gradually increased, the intestinal flora of this patient changed from a putrefactive to a moderately fermentative type. In the case of Emil C. (Table 4) altho the issue is somewhat confused by the alternation at one stage of a high fat with a high carbohydrate diet, practically the same degree of change is revealed. In Table 3 are detailed the results with two patients (Howard F. and Charles F.) of definite, but somewhat less, putrefactive tendencies than the ones just mentioned. Neither of them could tolerate liberal feeding for nearly a month after admission to 
the hospital. On the comparatively moderate amounts of carbohydrate which were given them during the first three weeks, there was, at first, some increase in the numbers of colon bacilli and streptococci followed by a moderate multiplication of the bacillus acidophilus, as indicated by the increased growth in the acetic acid glucose broth tubes and the differential counts from the fecal smears. Toward the end of the period of the observation, the amount of carbohydrate fed was greatly increased, but even under these conditions there was nothing like the substitution of floras which was revealed so strikingly for the two cases reported in Table 1.

The increase in the acidophilus types, which are believed to multiply principally in the large intestine and which are dependent upon carbohydrate in their metabolism, would seem to indicate that the amount of carbohydrate given to most of these cases was sufficient to encourage the bacilli of the colon group to exercise their fermentative, rather than their putrefactive, propensities. Du Bois ${ }^{19}$ determined, in a study of the food absorption in typhoid fever, that when carbohydrate was given in amounts under $300 \mathrm{gm}$. a day, it was present in the stools only in traces, if at all, whereas, when amounts over 300 $\mathrm{gm}$. were fed, the stools sometimes contained $2-3 \mathrm{gm}$. of reducing bodies. These results, it should be observed, were obtained with material which had passed through the whole length of the intestinal tract and had been subjected not only to absorption but to the action of fermentative bacteria. It seems altogether probable that with the large amounts of lactose fed in addition to other carbohydrates some of this sugar may have reached the level of the colon in sufficient quantity to exert a sparing action in that locality on the bacterial nitrogen metabolism. I have found that it is necessary to add only very small amounts of dextrose to Dunham's peptone medium in order to prevent the formation of indol by colon bacilli. Seeding tubes with the bacillus coli communis and also with the bacillus coli communior, indol had formed in medium containing 0.1 percent of ciextrose, but not in that containing 0.2 percent. This same result was obtained after 3 days' incubation at $37 \mathrm{C}$. and also after seven days' incubation. It is evident, then, that the presence of only slight amounts of a usable carbohydrate are necessary in order to prevent the peptolytic action of the bacillus coli.

19. Arch. Int. Med., 1912, 10, p. 177. 
In six patients, the initial flora, that is, the one observed before carbohydrate had been given in liberal amount or at most for not more than a few days, was markedly fermentative in type. The bacterial findings in four of these cases are given in detail in Table 2 . The dominant bacteria in the stools were from the start of the bacillus acidophilus type and there was a notable absence of putrefactive organisms. Accordingly, there was present in these cases at the beginning of the attack a type of flora which was attained in certain patients, with an initial facultative type, only after two weeks or more of feeding with large amounts of carbohydrate. As might be anticipated in these cases, the high carbohydrate diet maintained and accentuated this purely fermentative and relatively non-gas-producing flora. It seems not unlikely that if perforation should occur in cases with a flora of this character, the results might be less disastrous than for patients harboring an intestinal flora of putrefactive propensities.

As far as the incidence of the typhoidal infection is concerned, there was no evidence that it was favored by one type of intestinal flora more than by another; this series of cases exhibited intestinal bacterial conditions in the early stages of the attack which ranged from the putrefactive to a benign type of fermentative flora. Of course, the conditions at the time of primary infection may only be surmised, altho there is no reason to suppose that they differed markedly from what was encountered on their admission to the hospital.

With most of the cases especially in the earlier stages of the feeding, the daily amount of fat in the diet ranged from 75-125 gm. The effect on the cultural results of a sudden shift to a diet containing a larger ration of fat apparently depended upon whether the carbohydrate allowance was simultaneously decreased or was maintained at a high level. If, after a fermentative flora had been established, the fat in the diet was increased to about $200 \mathrm{gm}$. and the carbohydrate reduced to the same amount or less, there occurred a reduction in the number of viable bacteria in the stool which generally included the colon types, but was especially striking as regards the aciduric types. In the case of Christian M. (Table 2) the bacillus acidophilus was apparently almost eliminated, but on a return to the high carbohydrate feeding, it had again regained its dominance within three days. It should be observed that the amount of protein was kept at the same level in the diet of this case and only the fat and carbohydrate were varied in amount. If the amount of fat was increased to about 
$200 \mathrm{gm}$. daily, but, at the same time, the carbohydrate was maintained at $300-400 \mathrm{gm}$., any reduction in the number of viable bacteria in the stools which might occur concerned alone the bacilli of the colon group and the numbers of acidophilus bacilli remained at a high level (Table 2, Anthony G., Table 1, John T.). During the convalescence of Enrico P., about equal amounts by weight of protein, fat, and carbohydrate were given for a period of ten days. This resulted in an almost complete elimination of the bacillus acidophilus and an increase in the numbers of colon bacilli, the appearance of the direct smear from the feces changing from a predominately gram-positive type to an equally markedly gram-negative one (Table 1). I intend to enquire farther into the effect of varying the amounts of fat and carbohydrate on the intestinal flora. My results thus far indicate that fat is not potentially related to carbohydrate from a bacterial standpoint as has been suggested by Kendall. ${ }^{3}$

The stools of patients on a high carbohydrate diet were almost always moist and semi-formed, whereas those from patients on a high fat diet were formed and generally rather dry. The question arises, then, whether the cultural results with the stools of patients on a high fat diet reflect the bacterial conditions in the lower ileum and colon or whether the inspissation of such stools in the passage through the lower colon and rectum was the factor responsible for the variations in the numbers of viable bacteria. As regards the colon bacillus, altho the increase and decrease of their colonies could not always be correlated with the degree of moisture in the movement, yet frequently a low count was associated with a rather dry formed stool as MacNeal and his associates found in their series of examinations. On the other hand, the inspissation of the stool seemed to bear no relation to the numbers of the bacillus acidophilus which might appear in the cultures, but their increase and decrease, as revealed in the stool examinations, were governed entirely by the relative and actual amount of carbohydrate in the diet. It is in fact well established that these aciduric bacilli withstand drying successfully. Accordingly, there are good grounds for the assumption that the numbers of the bacillus acidophilus revealed in the cultures constitute a true index of their numbers at the level of the intestinal tract which they frequent.

It seemed advisable to determine whether or not typhoid patients, given a purely milk diet, would exhibit changes in their fecal flora similar to those which were observed with patients on a high calory 
diet with a liberal proportion of carbohydrate. Through the courtesy of Dr. Lewis A. Conner, I had the opportunity of examining bacteriologically the stools of three such patients at the New York Hospital. Two of these patients (Table 5, Joseph P. and Torello D.) were given daily an average of about $52 \mathrm{oz}$. of milk. This constitutes a liberal feeding of milk, but, nevertheless, is a low calory diet. This amount was probably equivalent to about 975 calories, of which the carbohydrate amounted to approximately $70 \mathrm{gm}$., the fat to $52 \mathrm{gm}$., and the protein to $45.5 \mathrm{gm}$. This amount constituted no more than one-third to one-half the amount usually given in the Coleman high calory diet, even in the early stages of the disease. It would seem unlikely that this allowance of carbohydrate would prove sufficient to encourage or maintain a benign fermentative flora, and such proved to be the fact. In one of these milk-fed cases (Table 5, Joseph P.) a distinctively fermentative flora was encountered at the beginning of the trial, but after four days of milk feeding the organisms of the bacillus acidophilus type had decreased greatly in numbers and in eight days they were almost entirely replaced by colon and streptococcus types. The fecal flora had thus undergone a transformation to one potentially peptolytic and indol-forming. As there was a history of a milk diet for this patient for two weeks before admission to the hospital, about 3 weeks were apparently required to bring about the marked change in the character of the flora. In the second of these cases (Torello D.), during fifteen days on a milk diet, the initial moderately putrefactive type of flora was transformed to a peptolytic, but not to a purely fermentative, type. Toward the end of the period, there was a marked increase in the number of streptococci. A much greater variety of bacteria was observed in the gramstained smears and also on the culture plates seeded from the stools of these two milk-fed patients than was the case with patients fed liberal amounts of carbohydrate. In fact, the simplification of the flora, following a course of high carbohydrate feeding, was a very striking feature. On the milk diet, colon types which acted slightly or not at all on lactose were common, a state of affairs which suggests an explanation of the fact that greater volumes of gas were formed in the dextrose than in the lactose fermentation tubes. The stool examination of the third patient on the milk diet revealed the same general features as the other two. At the time of taking the specimen, she had been four days on the milk diet and there was, in addition, a history of milk feeding for one week before admission. 
As far as typhoidal cases are concerned, the bacteriological examination of these stools would seem to indicate that a daily diet containing such a small amount of carbohydrate as $70 \mathrm{gm}$. with about two-thirds as much each of fat and protein is not a combination which will encourage the development in the adult of a non-indol forming intestinal flora. On the other hand, the best results were attained, as regards the development and maintenance of a fermentative flora, when carbohydrate to the amount of $300-400 \mathrm{gm}$. was given daily. Ir is manifestly impossible to feed this amount of carbohydrate when milk alone constitutes the diet.

Altho the number of cases examined was too few to offer more than a suggestion, it is of interest to note that with five of six patients exhibiting a markedly fermentative flora, with the bacillus acidophilus dominant either before a diet containing much carbohydrate had been given at all or for not more than a few days, the infection ran a comparatively mild and short course. With the sixth patient exhibiting such a flora (Morris S., Table 2) altho the febrile period extended through two relapses, the patient's state of nourishment remained very good and convalescence was rapid. On the other hand, patients who suffered the severer attacks of the fever were those who harbored an initial flora of putrefactive tendency. Herter observed that individuals in middle life with an intestinal flora of the adolescent fermentative type were usually well nourished, free from nervous disturbances, and possessed of much reserve energy. When such individuals contract typhoid fever it seems not unlikely that their probable lifelong freedom from the continued absorption of the toxic products of a putrefactive fecal flora enables them to withstand the systemic invasion of the typhoid bacillus with greater success than can individuals who have been subjected to auto-intoxication for many years. I do not wish to lay stress on this suggestion at this time but it is well known that attacks of typhoid fever among children, in whom as a class auto-intoxication of intestinal origin is not a frequent factor, are often mild.

\section{BACTERIAL OBSERVATIONS}

Typhoid Bacillus.-A survey of the tables shows that the typhoid bacillus was isolated less frequently from this series of cases on the high calory diet than has been reported from certain other groups of cases on a less liberal diet. From a few patients, this bacillus was not isolated at all in examinations of the stools conducted at intervals dur- 
ing almost the whole course of the fever and through convalescence. In almost every examination, from three to five Endo plates of the large size were made from graded dilutions of the stool and every suspicious colony was subjected to differential tests. In this procedure, a slant of Russell's double sugar medium was seeded from the colony in question and, if the growth and color reaction proved at all characteristic of the bacillus typhosus, the identification was established through agglutination tests. In certain instances where the typhoid bacillus was not recovered from stools with the Endo plate method, it was isolated by Dr. Oscar Teague, using a selective plating method. These comparative tests were carried out on only a comparatively few stools, and where success was attained the fact is indicated in the tables by an asterisk. Pratt, Peabody, and Long ${ }^{20}$ observed no difference in the frequency of the isolation of the typhoid bacillus from the stools of patients on a milk diet and those on a more liberal diet, the amount and constitution of which is not definitely stated. A possible explanation of the infrequency of the isolation of typhoid bacilli from the stools of these patients on the high calory diet may be found in an unusual degree of acidity in the lower ileum and the colon, arising in that locality through the bacterial splitting of the large amounts of carbohydrate. The typhoid bacilli, eliminated from the gall-bladder, in their passage through the intestinal tract would probably find this environment unfavorable and the survivors might be so few as to be crowded out on the Endo plates by colonies of the ordinary intestinal bacteria. In this connection, it may be mentioned that Kendall noted a tendency of dysentery bacilli to disappear from the stools of infants suffering from summer diarrhea when lactose was fed in quantity sufficient to change the flora from a putrefactive to a fermentative type.

Streptococci.-Without regard to the general character of the flora and the nature of the diet, streptococci were present in considerable numbers in most of the stools. Streptococcus is apparently an organism which can adapt itself readily to changing and diverse conditions. On a liberal carbohydrate diet, streptococci generally increased rapidly during the first week or so but were largely replaced later by the bacillus acidophilus (Table 1). With a milk diet, the streptococci increased rapidly and continued to be present in large numbers in the stools. On the Endo plates, the streptococcus colonies ranged 
from white to a deep scarlet. The white or pink colonies generally outnumbered the red and, by cultural tests, were found either to be raffinose fermenters and, hence, possibly to be grouped with the streptococcus salivarius, or to conform to the general type of the streptococcus lacticus. Certain of the deep red streptococcus colonies, which were subjected to differential tests, were found to be mannite splitters and in other respects to resemble the type, Str. fecalis.

Bacillus Acidophilus.-Rahe ${ }^{21}$ has investigated the biological characteristics of the bacillus acidophilus strains recovered from the stools of these typhoid cases and also cultures isolated from other sources. He has determined that the bacillus acidophilus group may be separated from the bacillus bulgaricus group, in a measure, through the type of colony formation on glucose oleate agar, but especially by the fact that the bacillus acidophilus ferments maltose whereas the bacillus bulgaricus is not able to split this sugar. The bacilli of the bacillus acidophilus type, according to his findings, may be further divided into two groups: those which clot milk within six days at $37 \mathrm{C}$., and those which do not clot milk within that period, and probably not at all. In a study of the strains of the bacillus acidophilus isolated from these typhoidal stools, it was found that in instances where the first examination from a patient disclosed large numbers of the bacillus acidophilus in the stool or where this bacillus became the dominant organism as the result of feeding large amounts of carbohydrate, the bacillus acidophilus present belonged in his Group 2, which clots milk readily, whereas cultures isolated from cases in which bacillus did not increase markedly as the result of such feeding belonged in his Group 3, which does not clot milk within six days' incubation.

Other Bacteria.-The bacillus pyocyaneus was found in the stools during the earlier stages of the disease in a few of the cases. These cases included both mild and severe types. This bacillus, in each instance, disappeared from the feces after the patient had been fed for a time with a high carbohydrate diet. No proteus-like colonies were observed on any of the plates. As has been mentioned, spores occurred in relatively small numbers in the most of the stools. In a number of the patients to whom carbohydrate was given in large amount, practically no spores developed on either the aerobic or anaerobic plates, but following a high-fat diet colonies developing from spores appeared in increased numbers on the aerobic plates. These were mostly thin,

21. Jour. Infect. Dis., 1914, 15, p. 141. 
dry, spreading, and frosted in appearance. Such spores as developed on the anaerobic plates were largely of the bacillus aerogenes capsulatus type. Spores of the bacillus putrificus type were rarely observed in the smears from the feces. Louis-Melikov ${ }^{22}$ has emphasized the supposed part played by anaerobic proteolytic bacilli, resembling the bacillus perfringens, in the production of the intestinal lesions. He has designated them "satellite bacilli." In our series of cases, neither the cultures nor the examinations of the smears has revealed unusual numbers of the spore-bearing bacilli of the type he describes. In the smears from the stools of some of the patients, many yeasts were observed. In one instance (Table 2, Morris S.), the frothy character of the stools was apparently due to them.

\section{SUMMARY}

In a series of typhoid cases, the intestinal flora as revealed by examinations of the stools soon after the admission of the patients to the hospital was not uniform or specific in type, but exhibited variations that might be observed in a series of supposedly normal individuals. Apparently, the character of the intestinal flora is not a factor concerned in the determination of susceptibility to typhoidal infection.

On a diet consisting of a daily average of $50-100 \mathrm{gm}$. of protein, 75-100 gm. of fat, and $250-300 \mathrm{gm}$. of carbohydrate, including lactose, the intestinal flora tended to become simplified in regard to the variety of bacterial types observed in direct gram-stained smears from the fecès and in cultures and to become converted into a fermentative type in which the dominant organism was Bacillus acidophilus. The degree of this transformation was dependent largely upon the type of flora which was present at the onset of the disease. When the flora showed a definite putrefactive tendency, the change did not extend farther than the elimination of the obligate putrefactive organisms and a moderate development of the aciduric types; while, with a more favorable initial flora, the change was of so radical a type that the stools finally resembled those of the first fer years of normal infancy in the dominance of the bacillus acidophilus and even in the presence of the bacillus bifidus. Such a flora is not an obligate fermentative one and under the conditions of feeding is not capable of forming indol. Observations on a few patients given a purely milk diet indi-

22. Ann. de l'Inst. Pasteur, 1913, 27, p. 541. 
cated that this food alone does not bring about this transformation of the intestinal flora to such a degree as that which may follow a more liberal carbohydrate feeding.

Patients exhibiting an initial fermentative flora of the aciduric type adapted themselves more readily to the high calory diet of Coleman, as shown especially by a comparative freedom of distention, than did patients with floras of putrefactive tendencies; in such patients, the diseases showed a marked tendency to run a mild course.

The typhoid bacillus was isolated from the stools of these patients on a high calory diet less frequently than has been reported for other series of cases in which the feeding was less liberal. 